OPEN ACCESS

Edited by:

Tiegang Fang,

North Carolina State University,

United States

Reviewed by:

Hongsheng Guo,

National Research Council Canada

(NRC-CNRC), Canada

Tingting $\mathrm{Li}$,

Ford Motor Company, United States

*Correspondence:

Zissis Samaras

zisis@auth.gr

Specialty section:

This article was submitted to

Engine and Automotive Engineering,

a section of the journal

Frontiers in Mechanical Engineering

Received: 28 February 2018

Accepted: 18 June 2018

Published: 31 July 2018

Citation:

Dimitriadis A, Natsios I, Dimaratos A, Katsaounis D, Samaras Z,

Bezergianni S and Lehto K (2018)

Evaluation of a Hydrotreated Vegetable Oil (HVO) and Effects on

Emissions of a Passenger Car Diesel

Engine. Front. Mech. Eng. 4:7.

doi: 10.3389/fmech.2018.00007

\section{Evaluation of a Hydrotreated Vegetable Oil (HVO) and Effects on Emissions of a Passenger Car Diesel Engine}

\author{
Athanasios Dimitriadis ${ }^{1}$, loannis Natsios ${ }^{2}$, Athanasios Dimaratos ${ }^{2}$, Dimitrios Katsaounis ${ }^{2}$ \\ Zissis Samaras $^{2 *}$, Stella Bezergianni ${ }^{1}$ and Kalle Lehto ${ }^{3}$ \\ ${ }^{1}$ Center for Research and Technology Hellas, Chemical Process \& Energy Resources Institute, Thessaloniki, Greece, \\ ${ }^{2}$ Laboratory of Applied Thermodynamics, Department of Mechanical Engineering, Aristotle University of Thessaloniki, \\ Thessaloniki, Greece, ${ }^{3}$ Neste Corporation, Espoo, Finland
}

In the coming years, the application of paraffinic biofuels, such as Hydrotreated Vegetable Oils (HVO), in the transportation sector is expected to increase. However, as the composition of HVO is different compared to conventional diesel, the engine optimized for conventional fuel cannot take full advantage of the HVO beneficial properties. Suitable adjustment of a number of engine parameters, if not complete engine re-calibration, will enable the full exploitation of such fuels' potential for lower exhaust emissions and reduced fuel consumption. In the present work, the emission characteristics of HVO fuel in a light-duty Euro 5 diesel engine have been studied, under steady-state operation, as well as during the New European Driving Cycle (NEDC). The study was expanded to the investigation of exhaust emissions under modified Main Injection Timing (MIT) and EGR rate. The NEXBTL fuel, produced by Neste, was considered in the study and was compared with conventional market diesel. Emissions of nitric oxides $\left(\mathrm{NO}_{\mathrm{x}}\right)$, soot, carbon monoxide $(\mathrm{CO})$, carbon dioxide $\left(\mathrm{CO}_{2}\right)$, and hydrocarbons $(\mathrm{HC})$ were studied. At default MIT and EGR settings the use of HVO resulted in a significant reduction of all regulated emissions. In addition, it was observed that the adjustment of MIT and EGR can enhance the exploitation of HVO potential for emissions reduction, highlighting the differences with the conventional diesel fuel.

Keywords: second-generation biofuels, hydrotreated vegetable oil, diesel engine, pollutant emissions, combustion

\section{INTRODUCTION}

The increasing demand on fossil fuels, the rising price of crude oil and the necessity of reducing greenhouse gas emissions have led to a substantial effort to develop alternative energy sources. Biofuels have attracted considerable attention during the past decade as renewable, biodegradable and non-toxic fuels. The European regulation of 2009 (directive 2009/28/EC) introduced new targets for European Union members. In particular, each member state shall ensure that the share of energy from renewable sources in all forms of transport in 2020 is at least $10 \%$ of the total energy consumption. Since the introduction of other renewable energy sources in road transport is rather difficult to be achieved at short term without shifting to alternative powertrains (e.g., hybrids, fuel 
cells etc.), it is expected that the goal set by the new regulation will be mainly met through extensive use of biofuels (Rakopoulos et al., 2006; Kousoulidou et al., 2012). Nowadays, the most widely used first-generation biofuels are FAME, more usually stated as biodiesel, and bioethanol. Biodiesel is the most commonly used biofuel in Europe, as it holds the $79.7 \%$ of total biofuel consumption (EurObserv'ER, 2015). Although diesel exhaust gasses are carcinogenic, however, Europe's roads remain dominated by diesel cars due to past decisions in favor of this technology. As concessions given by the EU Parliament allow the car manufacturers lead-time until 2020 to bring down the official diesel $\mathrm{NO}_{\mathrm{x}}$ emissions, this dominance is not expected to end on the short-term (Hooftman et al., 2018). Therefore, it is expected that biodiesel will continue to play a critical role in European market of biofuels.

Biodiesel can be produced from different types of raw vegetable oils from energy crops, used frying oils or animal fats using the conventional transesterification technology. It presents many benefits, such as higher cetane number, good lubricity, higher flash point, and no sulfur or aromatics (Kousoulidou et al., 2009). On the other hand, it has a series of effects on environment and urban air quality. Firstly, it has been observed that FAME usage on light-duty diesel engines and vehicles increases $\mathrm{NO}_{\mathrm{x}}$ emissions during both steadystate and transient operating conditions (George et al., 2007; Rakopoulos et al., 2008; Fontaras et al., 2009; Kousoulidou et al., 2010, 2012; Giakoumis et al., 2012). In the same direction, fuel consumption has also shown an increase due to FAME's lower energy content (Armas et al., 2013). However, it has been found that biodiesel usage on diesel engines leads to substantial reductions of particulate matter (PM) (Graboski and McCormick, 1998), carbon monoxide (CO), and unburned hydrocarbons (HC) (Karavalakis et al., 2009; Giakoumis et al., 2012). As far as engine operation is concerned, biodiesel has been associated with a deterioration of engine cold operability due to its higher viscosity, and relatively high $\mathrm{CP}$ and CFPP, that may affect injection performance and cold-start properties. Despite the several advantages, biodiesel has not met the expectations for green and environmentally friendly substitute for conventional diesel fuel. High feedstock cost and the competition with food sources, inferior storage and oxidation stability, lower calorific value, inferior low temperature operability and higher $\mathrm{NO}_{\mathrm{x}}$ emissions are some of the disadvantages that makes it less competitive fuel (Soo-Young, 2014).

As a result, second generation biofuels have been developed to overcome the limitations of their first-generation counterparts. They are produced from new innovative processes and a wider range of sources of raw materials. Promising second

Abbreviations: BSFC, Brake Specific Fuel Consumption; BTL, Biomass-ToLiquid; CFPP, Cold Filter Plugging Point; CP, Cloud Point; CI, Compression Ignition; $\mathrm{CO}$, Carbon Oxide; $\mathrm{CO}_{2}$, Carbon Dioxide; DME, Dimethyl ether; ECU, Electronic Control Unit; EGR, Exhaust Gas Recirculation; FAME, Free Fatty Methyl Esters; FT, Fischer-Tropsch; GTL, Gas-To-Liquid; HC, Hydrocarbons; HDC, Hydro-decarboxylation; HDO, Hydrodeoxygenation; HVO, Hydrotreated Vegetable Oil; HWCO, Hydrotreated Waste Cooking Oil; IT, Injection Timing; NEDC, New European Driving Cycle; $\mathrm{NO}_{\mathrm{x}}$, Nitric Oxides; PM, Particulate Matter. generation biofuels for diesel engines are dimethylether (DME), paraffinic diesels such as Fischer-Tropsch (FT) diesel and hydrotreated vegetable or waste cooking oils (HVOs or HWCOs) (Kousoulidou et al., 2014). Dimethylether is a gaseous compound at room temperature so it requires new storage techniques, new fuel delivery systems, and engine modifications (Semelsberger et al., 2006). Fischer-Tropsch diesel is a high quality and clean paraffinic fuel which can be produced from coal, natural gas, or biomass through Fischer-Tropsch synthetic processes, while no engine modifications are required. It is similar to fossil diesel regarding energy content, density, viscosity and flash point; however, it is characterized by higher cetane number and nearzero sulfur and aromatic content (Huang et al., 2008; Bezergianni and Dimitriadis, 2013). According to the open literature, several experiments have shown that FT diesel on light- and heavyduty engines generally reduces exhaust emissions. For example, Alleman and McCormick (2003) found that FT diesel usage on a light-duty engine causes a significant reduction of all regulated emissions. Furthermore, Huang et al. (2008) reported that $\mathrm{CO}, \mathrm{HC}, \mathrm{NO}_{\mathrm{x}}$, and smoke emissions from an unmodified diesel engine operating on FT diesel were lower when compared with those of conventional diesel fuel operation. In conclusion, a significant disadvantage is that the production costs of FT diesel from biomass feedstock are not competitive enough with conventional diesel prices to enable commercial production (Happonen et al., 2012).

Hydrotreated Vegetable Oil (HVO) is a paraffinic bio-based liquid fuel originating from many kinds of vegetable oils, such as rapeseed, sunflower, soybean, and palm oil, as well as animal fats (Aatola et al., 2008). It can be used in conventional diesel engines, pure or blended with fossil diesel (petrodiesel). Although largely unproven, HVO substitutes directly petrodiesel or blend in any proportion with it, without modification of $\mathrm{CI}$ engines (SooYoung, 2014). As it has been mentioned for biodiesel, vegetable feedstocks compete with food production. Therefore, alternative non-food oils such as jatropha and algae oil as well as waste cooking oils will receive greater attention in near future so as to be able to replace a significant portion of fossil-based diesel (Kousoulidou et al., 2014).

Catalytic hydroprocessing of vegetable oils, animal fats, or waste cooking oils has been used as an alternative process to transesterification for producing biofuels. To obtain the $\mathrm{HVO}$, the triglyceride of the feedstock is hydrogenated in the first step and broken down into various intermediates, mainly monoglycerides, diglycerides, and carboxylic acids. These intermediates are then converted into alkanes by three different pathways: (i) Hydrogenation, (ii) Hydrodeoxygenation (HDO), and Hydrodecarboxylation (HDC) (Soo-Young, 2014). The conversion that occurs through these three reactions creates hydrocarbons similar to existing diesel fuel components (Mikkonen et al., 2012). This technology is a modern way to produce high-quality bio-based diesel fuels without compromising fuel logistics, engines, or exhaust after-treatment devices.

HVOs (or HWCOs) are straight chain paraffinic hydrocarbons with the chemical structure $\mathrm{C}_{n} \mathrm{H}_{2 n+2}$, free of sulfur and aromatics (Aatola et al., 2008). Storage stability of 
these fuels is good and water solubility low, while their cetane number is very high. Although cetane number is considered a quality indicator of diesel fuels, the high difference between the cetane numbers of conventional diesel fuel and HVO would require some adjustments in the engine control to compensate for the fuel igniting earlier in the cycle. The lubricity is very low due to the absence of sulfur (and oxygen) compounds in the fuel, therefore, lubricating additive is required (as in conventional diesel) to protect the injection system (Mikkonen et al., 2012). Moreover, the heating value per mass of HVO is higher due to the higher hydrogen content. Density is lower due to the paraffinic nature and the lower final boiling point. Regarding the cold flow properties, such as cloud point (CP) and cold filter plugging point (CFPP), these may also be different than those of diesel fuel depending highly on the feedstock and the reaction conditions that may lead to a certain yield of triglycerides (Šimacek et al., 2010). The cold properties of these fuels can also be controlled to meet the local requirements by adjusting the severity of the process or by additional processing (e.g., isomerization; Lindfors, 2010). It is noteworthy that the fuel properties of HVOs are similar to the properties of gas-to-liquid (GTL) and biomass-to-liquid (BTL) diesel fuel produced by FT synthesis (Kuronen et al., 2007; Aatola et al., 2008). In any case, the good fuel properties of HVOs or paraffinic synthetic fuels are necessary for their viable future, because fuel requirements set by legislation and fuel standards are becoming more stringent, due to new regulations for exhaust emissions, fuel economy, and on-board diagnostics.

Most of the studies available in the open literature have shown that paraffinic synthetic fuels or HVOs usually lead to exhaust emissions benefits and good engine performance. Substantial reductions in $\mathrm{NO}_{\mathrm{x}}, \mathrm{PM}, \mathrm{CO}$, and $\mathrm{HC}$ emissions are reported with the use of HVOs on heavy-duty engines (Rantanen et al., 2005; Kuronen et al., 2007; Aatola et al., 2008). The decrease of $\mathrm{CO}, \mathrm{HC}$, and $\mathrm{PM}$ emissions was dependent on the proportion of HVO in the blend. However, it should be pointed out that it was not possible to define any clear trends in $\mathrm{NO}_{\mathrm{x}}$ emissions of light-duty vehicles equipped with EGR. Kitano et al. (2005) has reported reduction of exhaust emissions of modern diesel engine using GTL fuel. A significant impact on engine-out PM, $\mathrm{HC}$ and $\mathrm{CO}$ emissions was observed, but only little effect on $\mathrm{NO}_{\mathrm{x}}$ emissions. Murtonen and Aakko-Saksa (2009) reported the emission results with biodiesel, HVO, FT diesel (GTL) and petrodiesel in three engines and five city busses. In most cases, all regulated emissions such as $\mathrm{NO}_{\mathrm{x}}, \mathrm{PM}, \mathrm{CO}$ and $\mathrm{HC}$ decreased with HVO and GTL fuel compared to petrodiesel, although $\mathrm{NO}_{\mathrm{x}}$ increases have also been observed. According to Mikkonen et al. (2012), where exhaust emission tests have been performed with 32 trucks and busses or their engines, and several passenger cars in vehicle and engine test beds, remarkable reductions of particulate mass, carbon monoxide (CO) and hydrocarbon (HC) emissions were noticed. It is also important that $\mathrm{NO}_{\mathrm{x}}$ emissions rather decreased or did not change. SooYoung (2014) found that the use of HVO enables appreciable reductions in $\mathrm{NO}_{\mathrm{x}}, \mathrm{PM}, \mathrm{HC}$, and $\mathrm{CO}$ emissions without any changes to the engine or its control in heavy-duty engines. However, the influence of $\mathrm{HVO}$ on $\mathrm{NO}_{\mathrm{x}}$ emission was not so clear because of various EGR-strategies. Kitano et al. (2005) noticed that for light-duty vehicles, the effect of GTL on $\mathrm{NO}_{\mathrm{x}}$ and PM results vary between cars. One EGR equipped car resulted in low PM emissions, but slight $\mathrm{NO}_{\mathrm{x}}$ emissions disadvantage for GTL, which was deemed to be due to lower EGR rate. Another car optimized for low $\mathrm{NO}_{\mathrm{x}}$ emissions showed significant reduction with GTL, but poor PM emissions performance. The use of such fuels leads to alterations of exhaust emissions of light-duty engines, where it seems that the actual effect of the GTL-diesel blends is much dependent on the operation mode (Kitano et al., 2005). Different engine operating conditions may lead to opposite conclusions regarding the effect on $\mathrm{NO}_{\mathrm{x}}, \mathrm{PM}$, and smoke emissions (Armas et al., 2013; Happonen et al., 2013). This remark should always be considered when comparing the effects of HVO fuel between heavy-duty and light-duty engines.

In general, most of the studies examined HVO on heavyduty engines; as a result, there is insufficient data on light-duty engines of small passenger cars. Another observation is that in most cases, if not in all, HVO is examined under steady-state operation of the engine/vehicle and as a result there is lack of information during transient conditions, which are experienced for most of the operating life of a passenger car. Furthermore, $\mathrm{HVO}$ is investigated in existing engines only by changing the fuel. As HVO is a paraffinic fuel with different properties, due to its nature, the default settings of the engine are not optimum for its combustion. It is expected that, by careful interplay of engine settings, probably better exhaust emissions could be achieved. So far, there is limited knowledge on the effect of such fuels on emissions and it is clear that it should be investigated in depth because the demand on hydrotreated fuels is expected to increase further in the near future.

Taking all the above into consideration, the authors investigated experimentally the effect of $\mathrm{HVO}$ on exhaust emissions of a light-duty diesel engine equipped with common rail system and exhaust gas recirculation (EGR). In the first part of the study, the effect of HVO under steady-state operation was examined in the whole operating map of the engine. In the second part, the effect of HVO during a driving cycle (NEDC) was studied. Finally, in the third part, different EGR valve positions and Main Injection Timing (MIT) adjustments were examined at selected steady-state operating points. It was shown that by careful interplay mainly of MIT, better trade-off between soot and $\mathrm{NO}_{\mathrm{x}}$ emissions could be achieved. The target was first to evaluate the effect of HVO on regulated emissions and secondly, to obtain some first indications on how to recalibrate a light-duty diesel engine in order to gain full advantage of HVO's properties.

\section{METHODOLOGY}

\section{Fuel Properties}

In the present work two fuels were examined. A commercial market diesel from a fuel station in Greece was used as a reference fuel and a 2nd generation HVO was selected as a paraffinic hydrogenated biofuel. The reference market diesel complies with the EN590 specifications (Automotive fuels - diesel 
TABLE 1 | Properties of HVO (NEXBTL) compared to market diesel.

\begin{tabular}{|c|c|c|c|}
\hline Property & Unit & Market diesel & HVO \\
\hline FAME content & $\% \mathrm{v} / \mathrm{v}$ & 7 & 0 \\
\hline Density at $60^{\circ} \mathrm{C}$ & $\mathrm{kg} / \mathrm{m}^{3}$ & 832.4 & 778.7 \\
\hline Kinematic viscosity & $\mathrm{mm}^{2} / \mathrm{s}$ & 3.24 & 2.82 \\
\hline Flash point & ${ }^{\circ} \mathrm{C}$ & 59 & 83 \\
\hline Cloud point & ${ }^{\circ} \mathrm{C}$ & -5 & -22 \\
\hline Sulfur content & ppwt & 9.1 & $<5.0$ \\
\hline Cetane number & - & 56.5 & 76.3 \\
\hline Ash content & $\% \mathrm{~m} / \mathrm{m}$ & 0.002 & $<0.001$ \\
\hline Water content & $\mathrm{mg} / \mathrm{kg}$ & 160 & 20 \\
\hline Polyaromatic hydrocarbons & $\% \mathrm{~m} / \mathrm{m}$ & 2.2 & 0 \\
\hline CFPP & ${ }^{\circ} \mathrm{C}$ & -5 & -21 \\
\hline Heating value & $\mathrm{MJ} / \mathrm{kg}$ & 43 & 44 \\
\hline Oxidation stability & $\mathrm{hr}$ & $>6$ & $>22$ \\
\hline Distillation & ${ }^{\circ} \mathrm{C}$ & $191-357$ & 189-301 \\
\hline $\mathrm{A} / \mathrm{F}_{\mathrm{S}}$ & - & 14.2 & 15.2 \\
\hline Oxygen content & $\% w t$ & 0.77 & 0 \\
\hline $\mathrm{C} / \mathrm{H}$ ratio & - & 7.26 & 5.49 \\
\hline Hydrogen content & $\%$ wt & 12 & 15.4 \\
\hline Carbon content & $\% w t$ & 87.2 & 84.6 \\
\hline
\end{tabular}

- requirements and test methods, 2009) $)^{1}$ as a standard low sulfur fuel, typically containing 7\% vol. FAME. The HVO fuel is a $2^{\text {nd }}$ generation paraffinic biofuel that was produced from two stage hydrotreatment of vegetable oil and it complies with EN 15940 standard for paraffinic diesel fuels. HVO fuel was provided by Neste Corporation in Finland with the brand name NEXBTL $\left(\right.$ Neste Corporation $\left.^{2}\right)$. The properties of both Market Diesel and HVO are presented in Table 1.

HVO is a paraffinic fuel with light hydrocarbons and for that reason its density is lower compared to that of market diesel. Due to the lower density, HVO is characterized by lower volumetric heating value compared to market diesel. On the other hand, HVO has higher heating value per mass unit compared to market diesel due to its higher $\mathrm{H} / \mathrm{C}$ ratio. As $\mathrm{HVO}$ contains no oxygen, the oxidation stability is higher compared to market diesel, resulting in very good storage behavior. This fuel is fully paraffinic, and thus, the content of aromatics and sulfur is below the detectable limit. Finally, the high cetane number makes it a very good blending component for conventional diesel fuel in order to increase the cetane number or to produce premium diesel fuel grades.

\section{Engine Setup and Control}

The experimental work was conducted in the Laboratory of Applied Thermodynamics (LAT), Aristotle University of Thessaloniki, Greece. The tests were conducted on a Euro 5 turbocharged diesel engine which is used in passenger cars. The basic technical characteristics of the engine are presented in

\footnotetext{
${ }^{1}$ Automotive fuels - diesel - requirements and test methods, SIST EN 590:2009/A101

${ }^{2}$ Neste Corporation. NExBTL-second generation renewable diesel
}

TABLE 2 | Specifications of the test engine.

\begin{tabular}{ll}
\hline Engine characteristic & Details \\
\hline Number of cylinders & 4 \\
Displacement & $1,364 \mathrm{~cm}^{3}$ \\
Bore x stroke & $73.0 \times 81.5 \mathrm{~mm}$ \\
Rated power & $66.2 \mathrm{~kW} @ 3,800 \mathrm{rpm}$ \\
Compression ratio & 16.5 \\
Intake system & Variable geometry turbocharger with aftercooler \\
Fuel injection system & Common rail \\
Exhaust gas treatment & EGR \\
Emission standard & Euro 5 \\
\hline
\end{tabular}

TABLE 3 | Measuring equipment used in experiments.

\begin{tabular}{lll}
\hline Parameter & Measuring device & Accuracy \\
\hline Engine speed & AVL dynoperform dynamometer $\pm 1 \mathrm{rpm}$ \\
Brake torque & AVL dynoperform dynamometer $\pm 0.2 \% \mathrm{FSO}$ \\
Mass fuel consumption & AVL fuel flow meter $735 \mathrm{~S}$ & $0.1 \% \mathrm{FSO}$ \\
Emissions $\left(\mathrm{CO}_{2}, \mathrm{NO} \times \mathrm{CO}, \mathrm{HC}\right)$ & AVL AMA i60 gas analyzer & $< \pm 0.5 \% \mathrm{FSO}$ \\
Soot emissions & AVL Micro Soot sensor & $5 \mu \mathrm{g} / \mathrm{m}^{3}$
\end{tabular}

Table 2. The engine is integrated into a fully automated test bed and it is coupled to an eddy current dynamometer, which is suitable for both steady-state and transient test applications. This installation is characterized by excellent speed and torque control stability, making possible the precise adjustment of the engine desired operating conditions. The control of the test bed and the recording of the data are performed by the AVL Puma software.

The measurements performed at the current work included fuel consumption and regulated pollutant emissions. Engine operating parameters were recorded from the ECU. Engine speed and torque were measured by the dynamometer with very high accuracy. Concerning fuel consumption, the AVL 735S fuel mass flow meter was used, which also measures fuel density. The latter measurement is important when alternative fuels are tested, which may have significantly different density compared to the conventional diesel. The regulated pollutant emissions considered in this paper, measured at the engine exhaust before any after treatment device, were carbon monoxide (CO), carbon dioxide $\left(\mathrm{CO}_{2}\right)$, total hydrocarbons $(\mathrm{HC})$, nitrogen oxides $\left(\mathrm{NO}_{\mathrm{x}}\right)$, and soot. The concentration of the gas components in the exhaust stream was measured using the AVL AMA i60. The specific analyzer uses the standard methods for gas detection, namely, non-dispersive infrared absorption for $\mathrm{CO}$ and $\mathrm{CO}_{2}$, flame ionization for $\mathrm{HC}$, and chemiluminescence for $\mathrm{NO}_{\mathrm{x}}$. Soot emissions were measured with the AVL Micro soot sensor. Table 3 summarizes the equipment used during the specific tests and provides the measuring accuracy of each device.

\section{Experimental Protocol}

At first the engine was tested with both fuels (market diesel and HVO) over its whole operating range in order to analyze the emission maps for both fuels. The measurements were performed 
in thermally stabilized steady-state operating points. The engine was initially started with market diesel fuel and warmed up for $30 \mathrm{~min}$. Then the measurements with market diesel at all operating points were performed. If stable combustion was achieved (confirmed by the exhaust gas temperature measurement) the load was changed to the next consecutive point. In each operational point, engine was running for $15 \mathrm{~min}$ before measurements of the engine performance and exhaust emissions were taken. After the market diesel measurements, the same procedure was followed also for HVO fuel measurements. The exact operating points where the measurements were conducted are presented in Figure 1, while the pilot and main injection timing for diesel fuel for all operating points are presented in Table 6 in the Appendix. In the second phase of

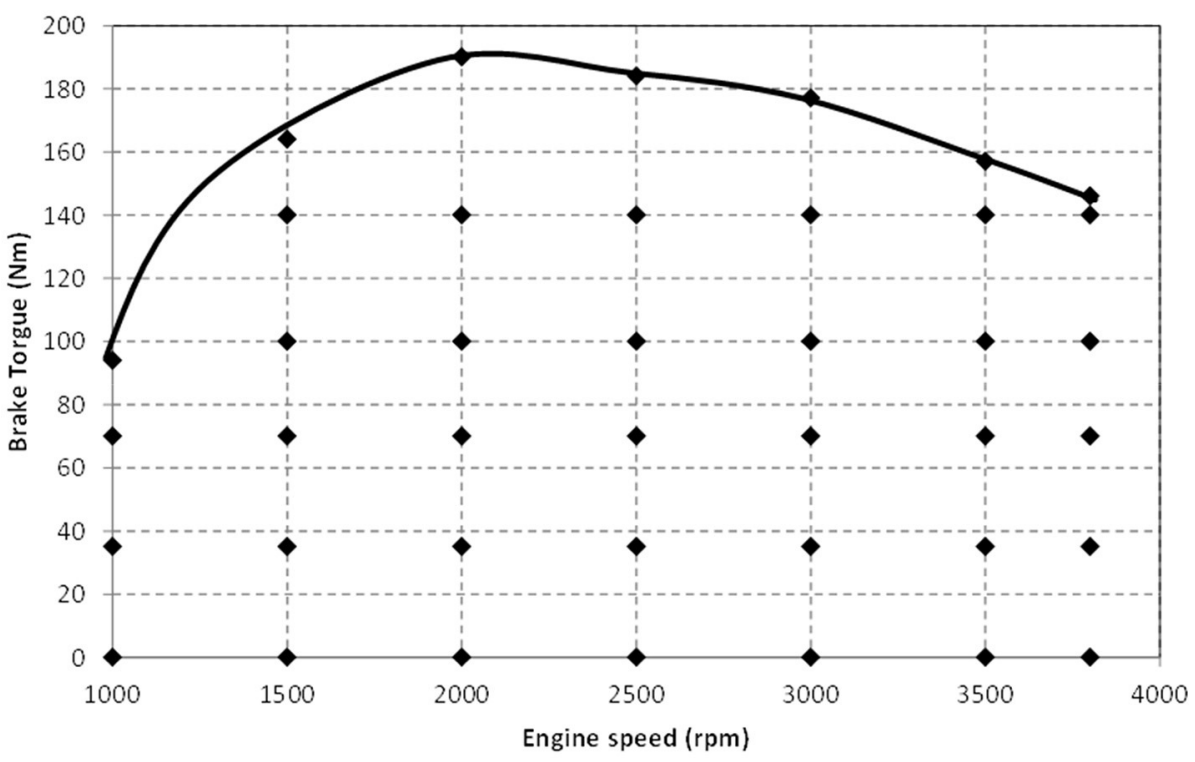

FIGURE 1 | Steady-state operating points of engine testing.

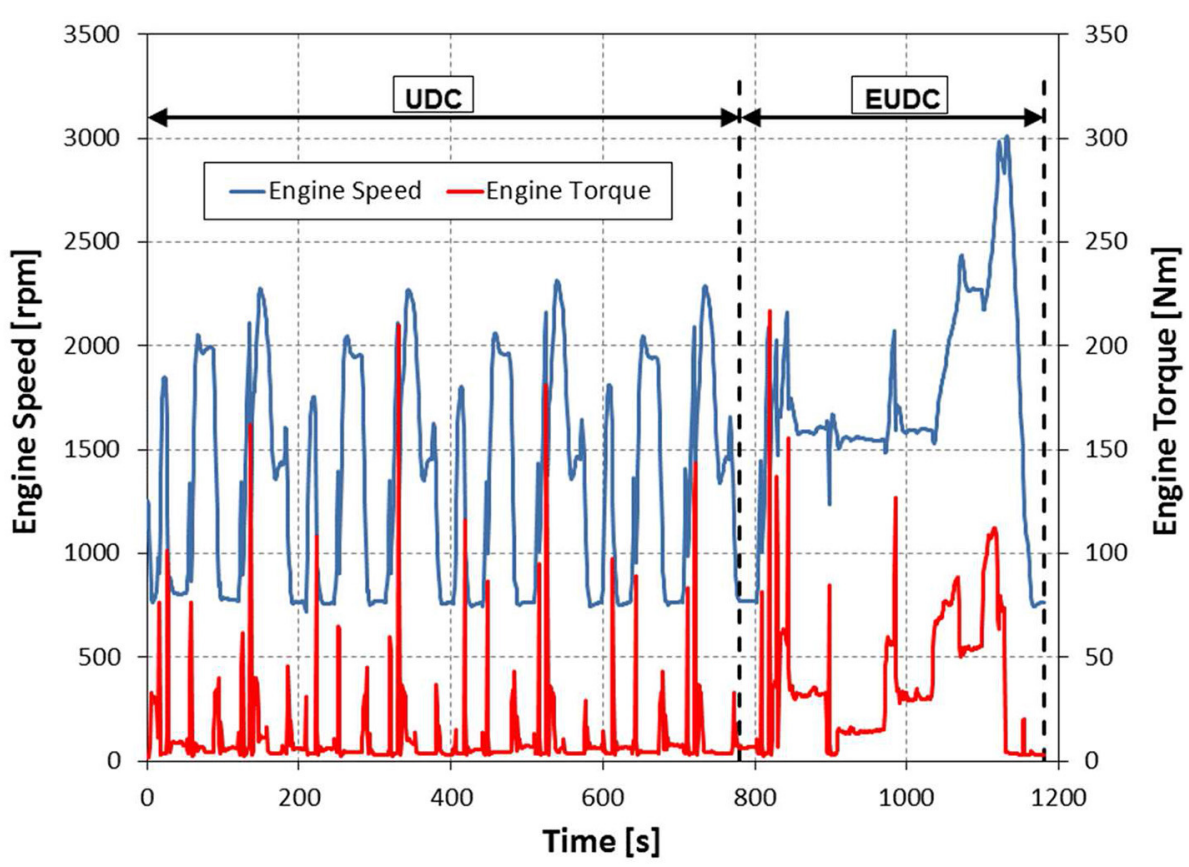

FIGURE 2 | Speed and Torque profile during the New European Driving Cycle (NEDC). 
the study, the New European Driving Cycle (NEDC) was tested with both fuels, and pollutant emissions were measured for both cold- and hot-start of the engine. Figure 2 presents the speed and torque profile of NEDC. Although this cycle has been replaced by WLTP in the type approval procedure, it still can be used for comparative evaluations of fuels.

On the third phase of the study, the effect of different main injection timing (MIT) and EGR settings was investigated. As it was already discussed in a previous section, the HVO fuel is characterized by different properties compared to market diesel, it has higher cetane number, higher heating value (per mass unit), no oxygen and sulfur content and no aromatics. It is obvious that the combustion of HVO would be different compared to that of market diesel affecting directly engine emissions. However, current engines are optimized for conventional diesel fuel, limiting the available data for operation on HVO. For this reason, an effort was made to examine the effect of EGR and MIT on engine performance and emissions, in order to gain full advantage of HVO fuel properties.

Main injection timing (MIT) and EGR effects were investigated at two steady-state points $(1,500 \mathrm{rpm} / 70 \mathrm{Nm}$ and 2,000 $\mathrm{rpm} / 70 \mathrm{Nm}$ ). Three MIT strategies were investigated, i.e., at the default settings, at $5^{\circ} \mathrm{CA}$ advanced and at $5^{\circ} \mathrm{CA}$ retarded as presented in Tables 4, 5, while all the other operating parameters of the engine were kept constant. As far as the effect of EGR is concerned, three different settings were examined, i.e., the default one, a higher EGR rate and a lower EGR rate with all the other operating settings kept constant. The EGR rate was quantified with the EGR valve position data. Tables 4 , 5 present the EGR rates that were examined. Finally, at each operating point, the engine speed and torque remained constant, independently of parameters variation, by adjusting accordingly the fuel supply. Therefore, the impact of each parameter on engine efficiency was also assessed.

\section{RESULTS AND DISCUSSION}

\section{Steady-State Conditions}

In this section 40 steady-state operating points were studied with market diesel and $\mathrm{HVO}$. A relative change of the measured emissions $\left(\mathrm{NO}_{\mathrm{x}}\right.$, Soot, $\mathrm{CO}_{2}, \mathrm{CO}$, and $\left.\mathrm{HC}\right)$, as well as volumetric and mass-based fuel consumption of the test engine was observed between the two fuels. However, it must be noted that during the operation, the engine parameters (such as injection timing, EGR etc.) were not locked to constant values. As a result, when the fuel changed from market diesel to HVO, some parameters of the engine also changed. The following figures (Figures 37) present the percentage change of the examined parameters; positive values declare an increase of the relevant parameter with the use of HVO, while negative values refer to reduction.

Figure 3 presents the percentage change of volumetric (left diagram) and mass-based (right diagram) fuel consumption of the engine when using HVO, compared to market diesel. An increase of volumetric fuel consumption is observed with $\mathrm{HVO}$ in all operating points, ranging from 2 to $8 \%$. This is due to the $6 \%$ lower density of HVO as compared to market diesel, confirmed also by previous research (Erkkila et al., 2011). On the other hand,
TABLE 4 | Test protocol for modified EGR and MIT at 1,500 rpm and $70 \mathrm{Nm}$.

\begin{tabular}{|c|c|c|c|c|}
\hline \multirow{2}{*}{$\begin{array}{l}\text { Case } \\
1\end{array}$} & \multirow{2}{*}{$\begin{array}{l}\begin{array}{l}\text { Operating } \\
\text { parameters }\end{array} \\
\text { Main Injection } \\
\text { Timing (MIT) [deg. } \\
\text { CA aTDC] }\end{array}$} & \multicolumn{3}{|c|}{ Parameter adjustment } \\
\hline & & $5^{\circ} \mathrm{CA}$ Retarded & Default & $5^{\circ} \mathrm{CA}$ Advanced \\
\hline & Market diesel & $5^{\circ} \mathrm{CA}$ & $0^{\circ} \mathrm{CA}$ & $-5^{\circ} \mathrm{CA}$ \\
\hline & HVO & $5^{\circ} \mathrm{CA}$ & $0^{\circ} \mathrm{CA}$ & $-5^{\circ} \mathrm{CA}$ \\
\hline \multirow[t]{3}{*}{2} & $\begin{array}{l}\text { EGR valve position } \\
(\%)\end{array}$ & Low & Default & High \\
\hline & Market diesel & $33 \%$ & $40 \%$ & $47 \%$ \\
\hline & HVO & $35 \%$ & $41 \%$ & $48 \%$ \\
\hline
\end{tabular}

TABLE 5 | Test protocol for modified EGR and MIT at 2,000 rpm and $70 \mathrm{Nm}$.

\begin{tabular}{lllll}
\hline $\begin{array}{l}\text { Case } \\
\text { parameters }\end{array}$ & $\begin{array}{l}\text { Operating } \\
\text { parameter adjustment }\end{array}$ \\
\hline 1 & $\begin{array}{l}\text { Main injection timing } \\
\text { (MIT) [deg. CA aTDC] }\end{array}$ & $5^{\circ}$ CA Retarded & Default & $5^{\circ} \mathrm{CA}$ Advanced \\
& Market diesel & $4^{\circ} \mathrm{CA}$ & $-1^{\circ} \mathrm{CA}$ & $-6^{\circ} \mathrm{CA}$ \\
& HVO & $4^{\circ} \mathrm{CA}$ & $-1^{\circ} \mathrm{CA}$ & $-6^{\circ} \mathrm{CA}$ \\
\hline 2 & EGR valve position & Low & Default & High \\
& (\%) & & & \\
& Market diesel & $53 \%$ & $58 \%$ & $64 \%$ \\
& HVO & $53 \%$ & $58 \%$ & $63 \%$ \\
\hline
\end{tabular}

the higher mass-based heating value of HVO results in lower mass-based fuel consumption by $2-4 \%$.

Nitric oxide $\left(\mathrm{NO}_{\mathrm{x}}\right)$ and soot emissions are the main pollutants of diesel engines. Figure 4 presents the effect of $\mathrm{HVO}$ on $\mathrm{NO}_{\mathrm{x}}$ emissions (left diagram). As observed in Figure 4, the effect of $\mathrm{HVO}$ on $\mathrm{NO}_{\mathrm{x}}$ emissions is not constant. It must be made clear that during measurements in four operating points the EGR valve position was not constant but varied with the fuel change affecting $\mathrm{NO}_{\mathrm{x}}$ emissions accordingly. The \% changes of EGR are presented in Table 7 in the Appendix. More specifically at 2,000 $\mathrm{rpm} / 100 \mathrm{Nm}, 2,000 \mathrm{rpm} / 140 \mathrm{Nm}, 2,500 \mathrm{rpm} / 140 \mathrm{Nm}$ and at $3,000 \mathrm{rpm} / 140 \mathrm{Nm}$ the changes of EGR were up to $35 \%$, however in all the other operating points the EGR changes were less than 5\%. Furthermore at 3,500 rpm and 3,800 rpm the EGR valve position was $0 \%$ for both fuels. As a result, the effect of HVO fuel on $\mathrm{NO}_{\mathrm{x}}$ emissions is comparable between the two fuels in the entire engine map with the exception of the four operating points that were described above. In order to eliminate the EGR effect, an engine model was also developed in AVL Boost software (2011) for the engine points of $2000 \mathrm{rpm} / 140 \mathrm{Nm}$ and $2500 \mathrm{rpm} / 140 \mathrm{Nm}$. The results have shown a slightly decrease of $\mathrm{NO}_{\mathrm{x}}$ emissions (1.5\%) with $\mathrm{HVO}$ fuel for these two points. According to Figure 4, in loads lower than $100 \mathrm{Nm}$ where the EGR valve position was constant and similar for both fuels, at low engine speeds, $\mathrm{HVO}$ presents reduced $\mathrm{NO}_{\mathrm{x}}$ emissions by $5-$ $10 \%$, however at higher engine speeds (from 3,000 to 3,800 rpm, 

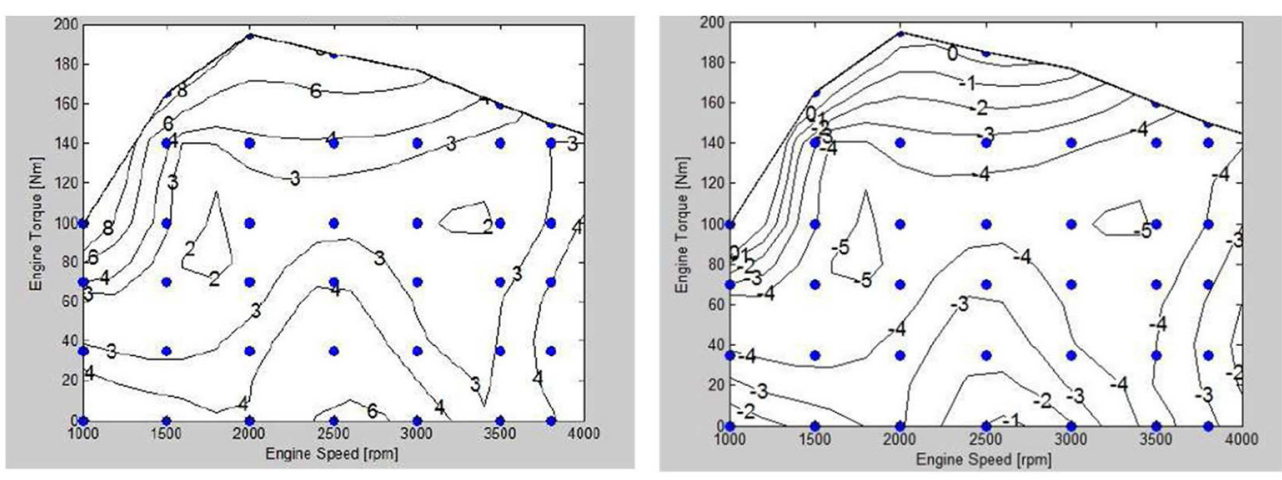

FIGURE 3 | Percentage change of volumetric fuel consumption (left), mass-based fuel consumption (right).

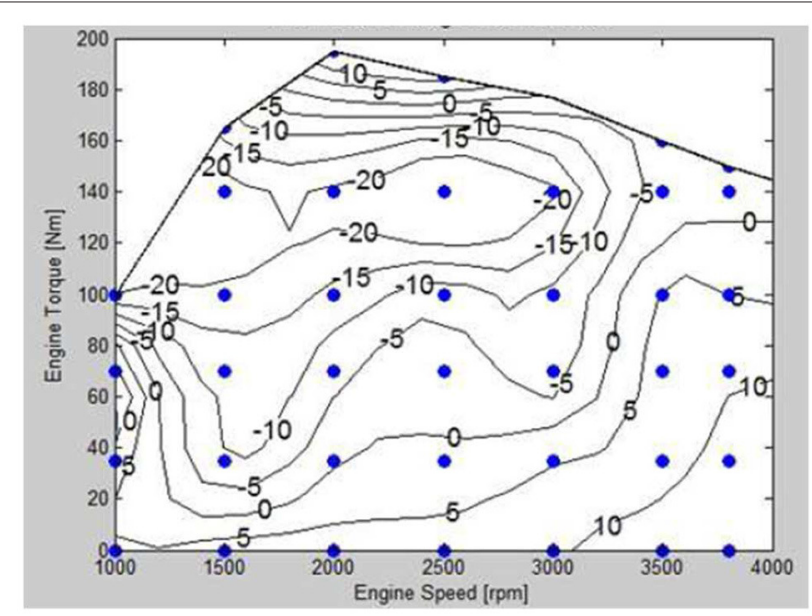

FIGURE 4 | Percentage change of $\mathrm{NO}_{x}$ emissions.

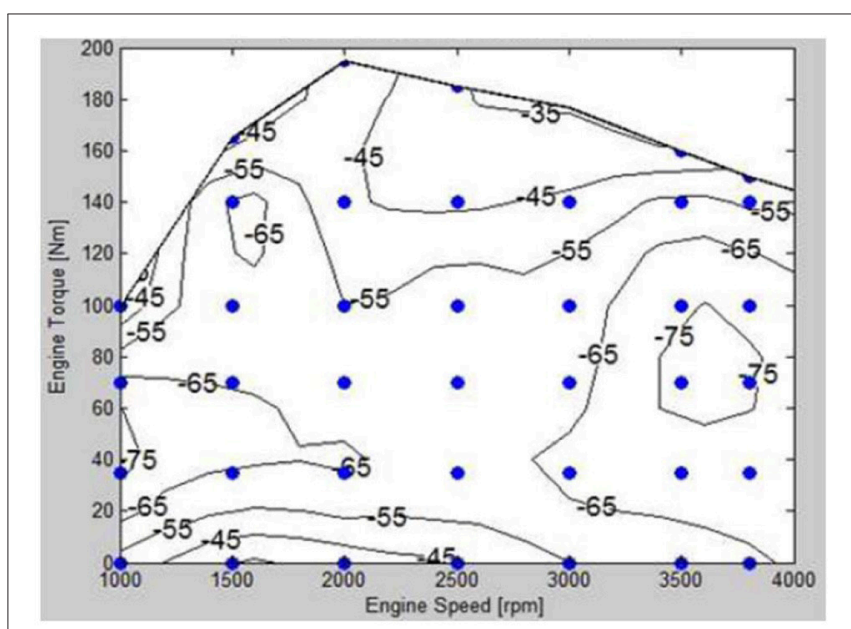

FIGURE 5 | Percentage change of soot emissions. where EGR was $0 \%$ for both fuels), HVO results in increased $\mathrm{NO}_{\mathrm{x}}$ emissions by $5-10 \%$. As far as full load is concerned, at low and high engine speeds $\mathrm{HVO}$ presents lower $\mathrm{NO}_{\mathrm{x}}$ emissions. Apart from EGR, a number of conflicting effects influence the formation of $\mathrm{NO}_{\mathrm{x}}$. On the one side, the absence of oxygen and aromatics in HVO (Table 1 ) prevent $\mathrm{NO}_{\mathrm{x}}$ formation, since aromatic compounds have higher adiabatic flame temperature producing higher local combustion temperatures (Glaude et al., 2010). On the other side, the very high cetane number of HVO (Table 1) may promote $\mathrm{NO}_{\mathrm{x}}$ formation, as it leads to a decrease of ignition delay, meaning that the start of combustion shifts earlier (well before the top dead center), resulting in earlier pressure and temperature rise. Overall, a clear conclusion concerning $\mathrm{HVO}$ effect on $\mathrm{NO}_{\mathrm{x}}$ emissions cannot be drawn, since a mixed effect is observed: in some operating points HVO presents lower $\mathrm{NO}_{\mathrm{x}}$ emissions, while in some others higher. This is the subject of further work of the present research team, combining experimental and simulation approaches.

Similar findings are reported in the open literature, where no appreciable reduction in $\mathrm{NO}_{\mathrm{x}}$ emissions has been observed for light-duty engines when running with HVO fuel. Rantanen et al. (2005), after testing the exhaust emissions of three cars running with $\mathrm{HVO}$ fuel, concluded that although $\mathrm{HC}$ and soot emissions were reduced, not clear reduction in $\mathrm{NO}_{\mathrm{x}}$ emissions was observed. Same results were also reported by Sugiyama et al. (2011), who mentioned that HVO can reduce HC and soot emissions due to high cetane number and zero aromatic content, but $\mathrm{NO}_{\mathrm{x}}$ emissions were similar with market diesel fuel. Pflaum et al. (2010), after conducting engine and vehicle testing with $\mathrm{HVO}$, did not notice appreciable reduction in $\mathrm{NO}_{\mathrm{x}}$ emissions.

On the other hand, tests performed on heavy-duty engines have shown that $\mathrm{NO}_{\mathrm{x}}$ emissions in some cases can be lower with HVO fuel. Aatola et al. (2008) after testing HVO fuel in a turbocharged common-rail heavy-duty engine without EGR, observed reduction in $\mathrm{NO}_{\mathrm{x}}$ emissions. Similar findings have been reported by Hajbabaei et al. (2012) in two heavy-duty engines, as well as by Makinen et al. (2011) who examined 300 city busses with $\mathrm{HVO}$ and observed an average $10 \%$ reduction of $\mathrm{NO}_{\mathrm{x}}$ emissions. Such results indicate that in heavy-duty engines the 

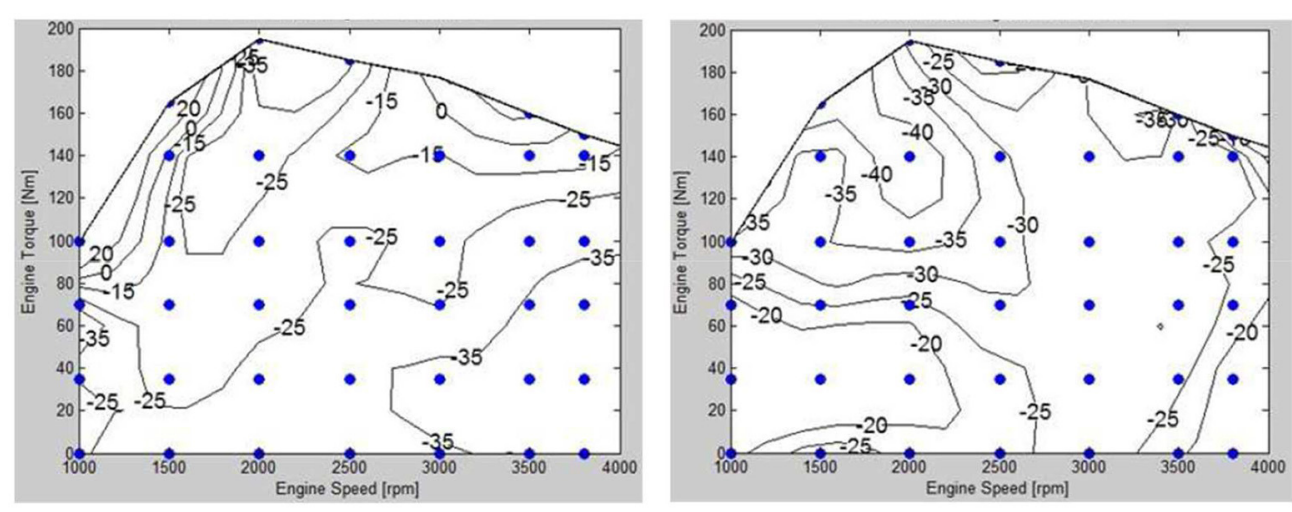

FIGURE 6 | Percentage change of CO (left) and HC (right) emissions.

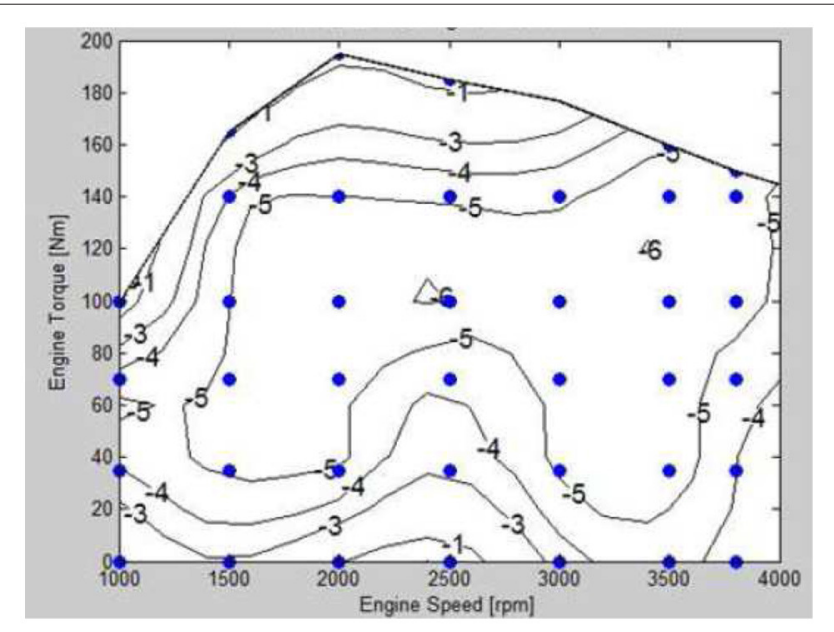

FIGURE 7 | Percentage change of $\mathrm{CO}_{2}$ emissions.

positive effect of $\mathrm{HVO}$, as concerns $\mathrm{NO}_{\mathrm{x}}$ emissions, may be more prominent.

The effect of HVO on soot emissions is presented in Figure 5. It is clear that this 2nd generation biofuel causes significant reduction in soot emissions in the whole engine operating range of up to $75 \%$, a finding that comes in agreement with previous research (Murtonen et al., 2009; Sugiyama et al., 2011). The reason is that $\mathrm{HVO}$ is an exclusively paraffinic fuel with higher $\mathrm{H} / \mathrm{C}$ ratio, no aromatics, sulfur and other mineral impurities that are responsible for soot formation (Rimkus et al., 2015).

Generally, $\mathrm{CO}$ and $\mathrm{HC}$ emissions are low in diesel engines (Heywood, 1988). Figure 6 presents the effect of HVO on CO (left diagram) and $\mathrm{HC}$ (right diagram) emissions of the engine on the whole engine operating range. According to Figure 6, $\mathrm{CO}$ emissions are lower for HVO by up to $35 \%$. Due to the lower ignition delay of $\mathrm{HVO}$, the combustion time is longer favoring in that way the oxidation process of $\mathrm{CO}$ emissions. The same trend is also observed for HC emissions, which are reduced by $20-40 \%$ with the application of HVO. Unburned HC result from various reasons, including flame quenching, overmixing and undermixing (Heywood, 1988). HVO is characterized by very high cetane number (Table 1), which reduces significantly the ignition delay, limiting the overmixing effect. Moreover, the lower density and the lower viscosity of HVO accelerate the mixture formation, reducing also the ignition delay. Pflaum et al. (2010), have found that a reduction of up to $50 \%$ in both CO and $\mathrm{HC}$ emissions can be achieved with $\mathrm{HVO}$ as compared to conventional diesel. Similar results were also observed by Kousoulidou et al. (2014) in a light-duty diesel engine running with HVO fuel.

Figure 7 presents the effect of $\mathrm{HVO}$ on $\mathrm{CO}_{2}$ emissions, where a small reduction by up to $6 \%$ is observed with HVO. These results come in agreement with the findings of Kuronen et al. (2007), Murtonen et al. (2009) and Rantanen et al. (2005). $\mathrm{CO}_{2}$ emissions represent well fuel consumption, which is reduced (in mass terms) with HVO, as already discussed in Figure 3. Further, the lower carbon content of HVO (resulting in higher $\mathrm{H} / \mathrm{C}$ ratio), as shown in Table 1, resulting from the lighter hydrocarbon compounds of $\mathrm{HVO}$ as compared to conventional diesel, further contributes to the reduction of $\mathrm{CO}_{2}$ emissions.

\section{Driving Cycle Operation-NEDC}

At this part of the current experimental investigation, the effect of HVO fuel on emission characteristics of a diesel engine during the New European Driving Cycle (NEDC) was examined. The evolution of cumulative mass of $\mathrm{NO}_{\mathrm{x}}$, soot, $\mathrm{CO}, \mathrm{HC}$, and $\mathrm{CO}_{2}$ emissions, as well as the fuel consumption are depicted in Figure 8 for hot-start operation and in Figure 9 for cold-start operation. Results are presented in the form of cumulative mass instead of instantaneous concentration values in order for the differences between the two fuels to be better distinguished.

According to Figures 8, 9, HVO results in lower cumulative $\mathrm{CO}_{2}$ emissions during NEDC. More specifically, during the hot NEDC the total $\mathrm{CO}_{2}$ emissions for $\mathrm{HVO}$ were $1,146 \mathrm{~g}$ and for market diesel were $1,194 \mathrm{~g}$, while during the cold NEDC these were 1,237 and $1,291 \mathrm{~g}$ respectively. $\mathrm{CO}_{2}$ emissions can be used as a first indication for fuel consumption (and, by that, for engine brake thermal efficiency, considering also the fuel's 


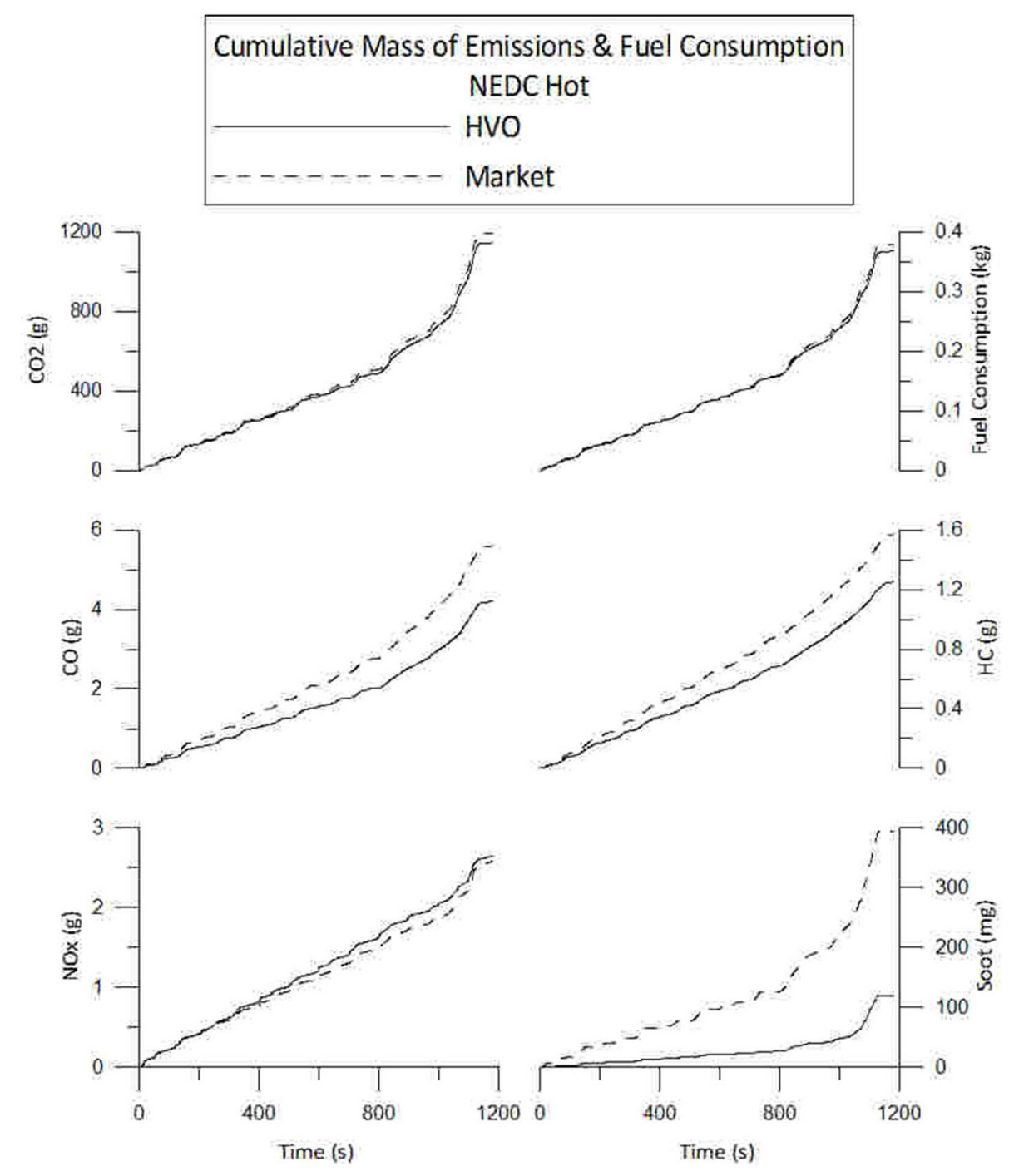

FIGURE 8 | Evolution of cumulative mass of $\mathrm{NO}_{x}$, soot, $\mathrm{HC}, \mathrm{CO}, \mathrm{CO}_{2}$ emissions and fuel consumption during the hot-started NEDC for Market Diesel and HVO.

heating value), although a direct comparison can be made feasible only for fuels with the same carbon content, $\mathrm{H} / \mathrm{C}$ ratio and not containing oxygen. The lower $\mathrm{CO}_{2}$ emissions for $\mathrm{HVO}$ fuel can be attributed to the lower $\mathrm{C} / \mathrm{H}$ ratio by $24 \%$, as compared to market diesel (Table 1). This is because HVO consists mainly of paraffins in the range of $\mathrm{n}-\mathrm{C} 15$ to $\mathrm{n}-\mathrm{C} 18$, while market diesel consists of hydrocarbons in the range of C9-C30.

Fuel consumption is another important factor for the car manufacturers. Figures 8, 9 present the evolution of cumulative mass-based fuel consumption for market diesel and HVO during the hot and cold NEDC, respectively. It is observed that there is a decrease of mass-based fuel consumption with HVO that comes from its higher heating value. More specifically, at the hot and cold NEDC the fuel consumption for HVO was 3 and $5 \%$, respectively, lower compared to market diesel. The lower mass-based fuel consumption with HVO is also one of the reason for the lower $\mathrm{CO}_{2}$ emissions that were observed during NEDC measurements above. These findings come also in agreement with the results from the steady-state operation analyzed in previous section.

As far as $\mathrm{CO}$ and $\mathrm{HC}$ emissions are concerned, strong differences are observed between the two fuels for both the hot and cold NEDC. When the engine was running with HVO, the cumulative mass of CO over the NEDC was decreased by $33 \%$ for the hot start operation and $48 \%$ for the cold start operation. For $\mathrm{HC}$ emissions, the respective reductions were $25 \%$ for the hot start and $47 \%$ for the cold start operation, compared with the market diesel case. These results come in agreement with the results of Aatola et al. (2008), Kuronen et al. (2007) and Kousoulidou et al. (2014), who have also reported reductions in $\mathrm{CO}$ and $\mathrm{HC}$ emissions in a diesel engine when running with paraffinic fuels. 


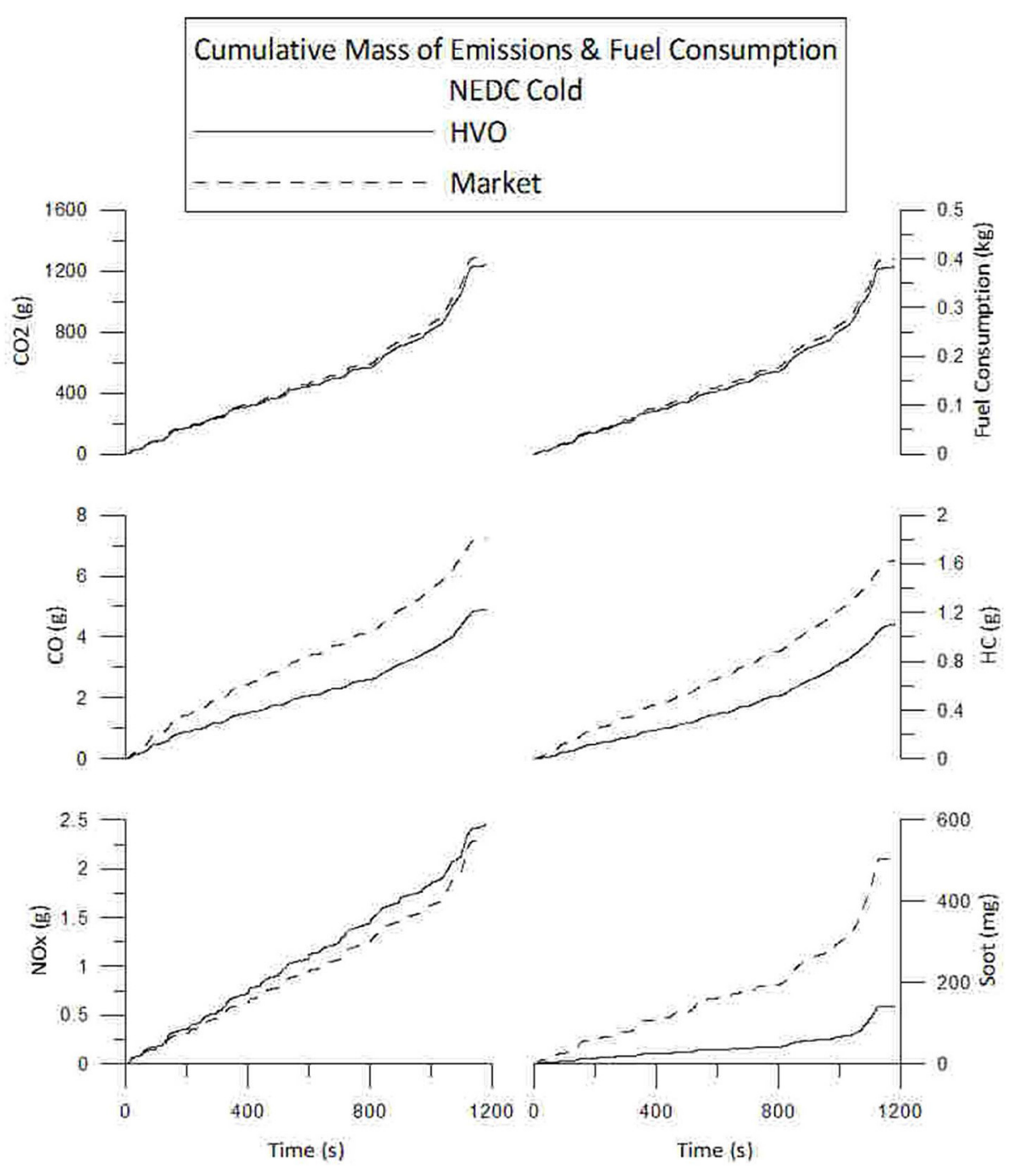

FIGURE 9 | Evolution of cumulative mass of $\mathrm{NO}_{X}$, soot, $\mathrm{HC}, \mathrm{CO}, \mathrm{CO}_{2}$ emissions and fuel consumption during the cold-started NEDC for Market Diesel and $\mathrm{HVO}$.

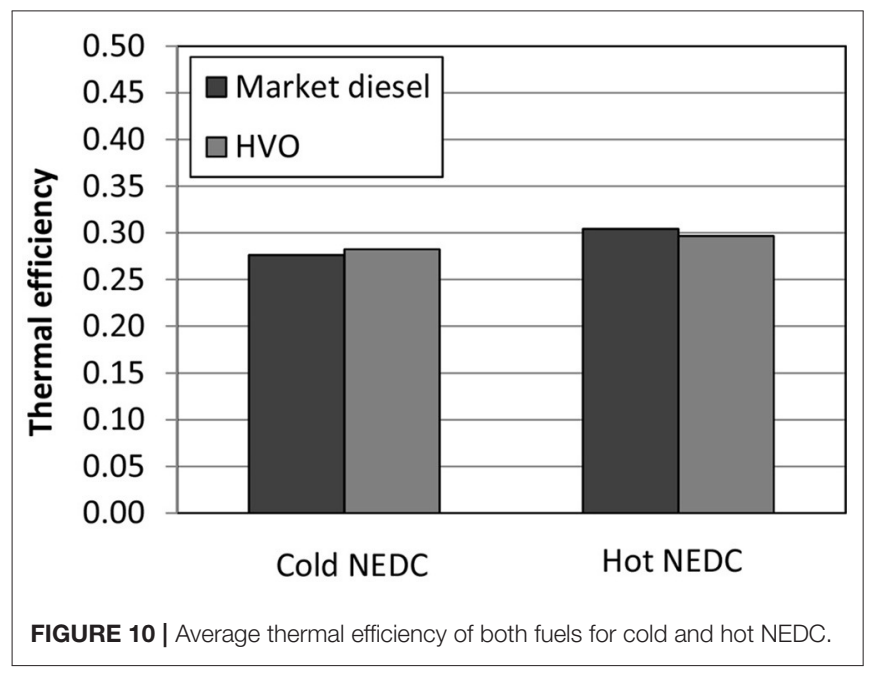

The effect of HVO fuel on $\mathrm{NO}_{\mathrm{x}}$ emissions during the NEDC is also shown in Figures 8, 9 for hot and cold start operation, respectively. It must be mentioned here that the EGR strategy during the NEDC remained the same for both fuels. It can be seen that there is a slight increase for HVO during both hot and cold start operation. This increase is 3\% for hot start operation and $6 \%$ for cold start operation. However, based on the review of Gill et al. (2011), covering both light- and heavy-duty engines and vehicles, it was found that $\mathrm{NO}_{\mathrm{x}}$ emissions show a decreasing trend with paraffinic fuels in many cases. On the other hand, according to Mizushima et al. (2012), the higher H/C ratio of paraffinic fuel compared to market diesel causes an increase in flame temperature, which results in higher $\mathrm{NO}_{\mathrm{x}}$ emissions. In any case, $\mathrm{NO}_{\mathrm{x}}$ formation, which is primarily governed by local in-cylinder temperature, oxygen availability, and residence time of the gas inside a critical temperature window (Heywood, 1988), depends on a variety of parameters, such as injection and EGR 
strategy, fuel properties, and spray characteristics. As a result, the final $\mathrm{NO}_{\mathrm{x}}$ concentration is a delicate balance among all these influences, and this is probably why a clear trend has not yet been established for light-duty diesel engines and cars fueled with paraffinic fuels (Rantanen et al., 2005; Kousoulidou et al., 2014).
A different trend is observed for soot emissions, which are significantly reduced with the application of HVO. At the case of hot NEDC, the cumulative soot emissions are reduced from $394 \mathrm{mg}$ for market diesel to $120 \mathrm{mg}$ for the HVO fuel, while at the cold NEDC the respective reduction is from $505 \mathrm{mg}$

\section{EGR effect on Emissions \& Fuel Consumption $1500 \mathrm{rpm}-70 \mathrm{Nm}$ -.... Market}
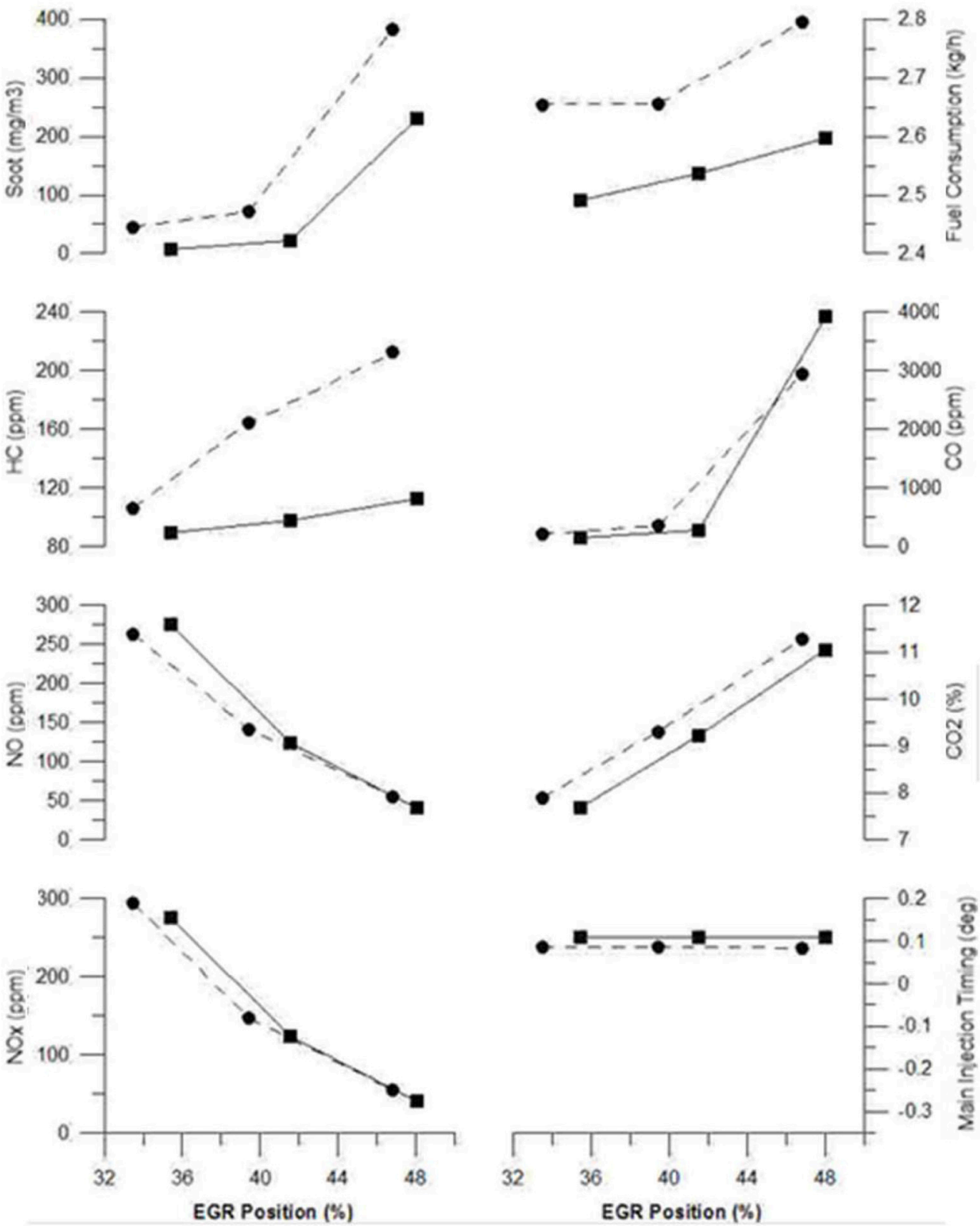

FIGURE 11 | EGR valve position effect on emissions and fuel consumption for HVO and market diesel at 1,500 rpm and 70 Nm. 
for market diesel to $143 \mathrm{mg}$ for HVO. As it was already mentioned, $\mathrm{HVO}$ is a paraffinic fuel with shorter molecular chain and higher $\mathrm{H} / \mathrm{C}$ ratio, with almost zero aromatic, sulfur and other mineral impurities content, which enhance PM formation, factors that all contribute to lower soot emissions (Rimkus et al., 2015).

Finally, the average thermal efficiency throughout the NEDC for both fuels is presented in Figure 10. The results show that during both cycles the average thermal efficiency receives similar values, 27 and 30\% for cold and hot NEDC, respectively. According to Duckhan et al. (2014), HVO presents slightly higher energy efficiency which is attributed to its almost zero oxygen content while according to Aatola et al. (2008), HVO presents similar or slightly higher thermal efficiency probably due to the higher cetane number and, therefore, shorter ignition delay.
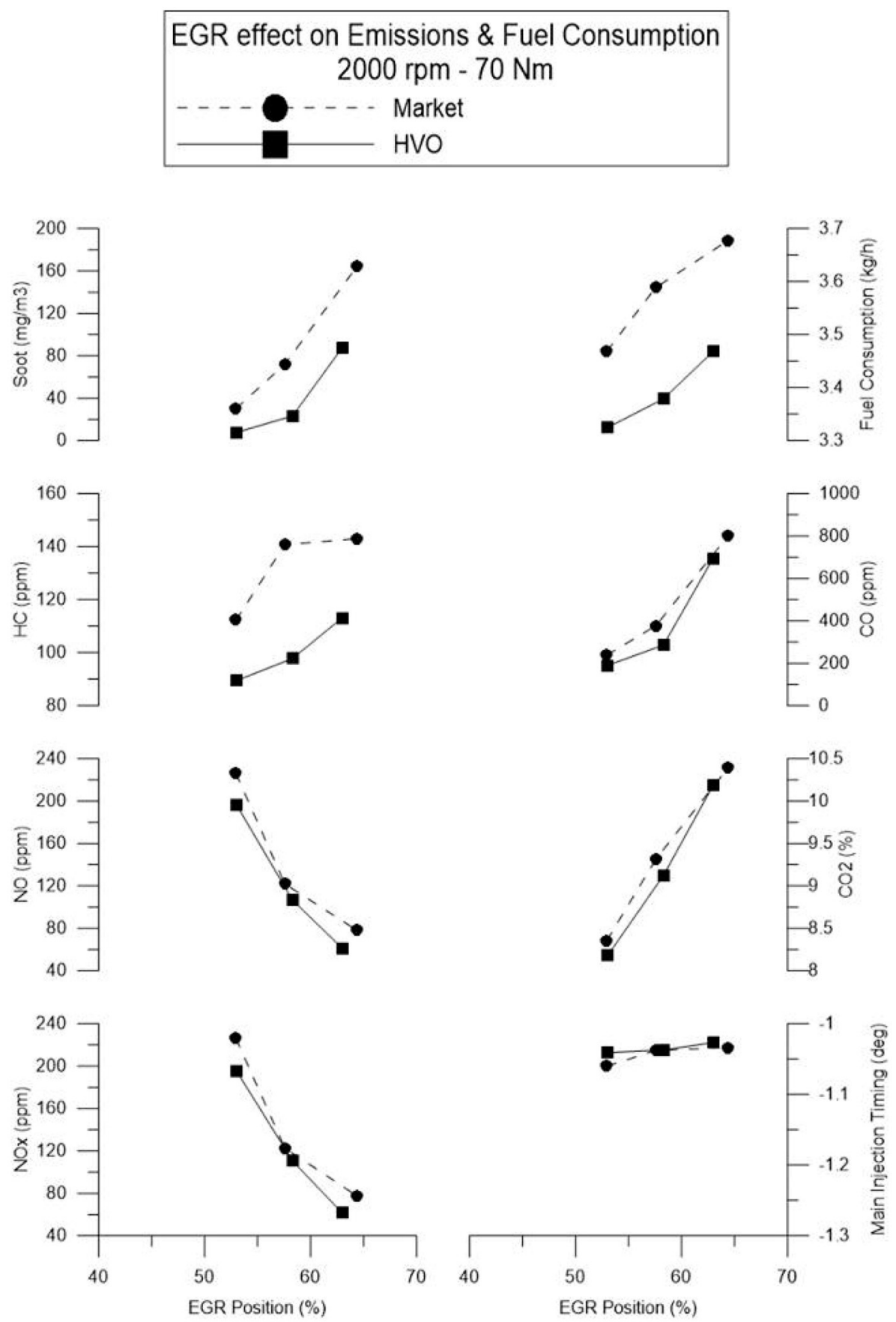

FIGURE 12 | EGR valve position effect on emissions and fuel consumption for HVO and market diesel at 2,000 rpm and 70 Nm. 


\section{Effect of EGR and MIT}

In the following paragraphs, the effect of Exhaust Gas Recirculation (EGR) and Main Injection Timing (MIT) on emissions of a diesel engine running with $\mathrm{HVO}$ fuel and market diesel is presented. All the results are presented for two steady-state operating points, at $1,500 \mathrm{rpm} / 70 \mathrm{Nm}$ and at 2,000 $\mathrm{rpm} / 70 \mathrm{Nm}$.

\section{EGR Effect}

The effect of EGR (exhaust gas recirculation) is quite significant and its influence on engine emissions has been widely studied. In internal combustion engines, EGR is a means for $\mathrm{NO}_{\mathrm{x}}$ emissions reduction. At this section, EGR effect on emission characteristics was examined, in order to explore the potential of the HVO fuel for further emission reduction. To this aim two steady-state operating points at 1,500 $\mathrm{rpm} 70 \mathrm{Nm}$ and at $2,000 \mathrm{rpm} / 70 \mathrm{Nm}$ were examined for both fuels, with three EGR valve positions being tested (Tables 4, 5).

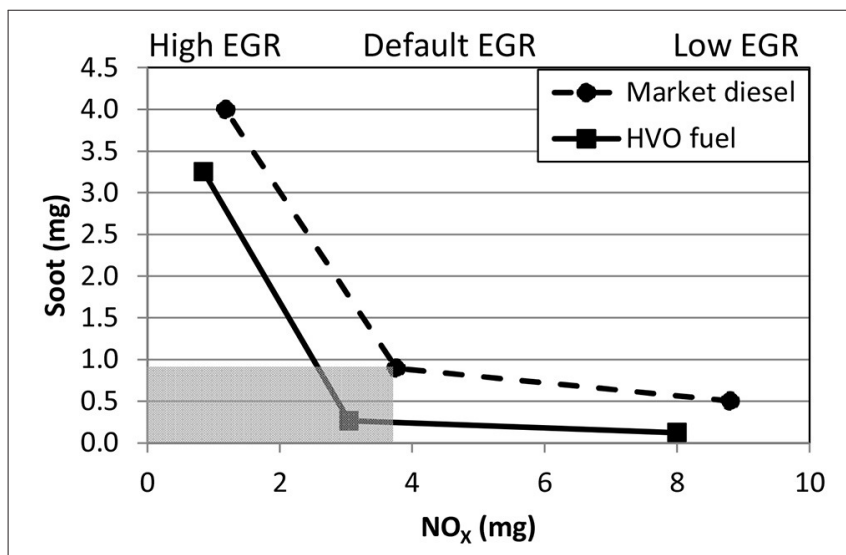

FIGURE 13 | Effect of EGR on the trade-off between $\mathrm{NO}_{x}$ and soot emissions (1,500 rpm/70 Nm).

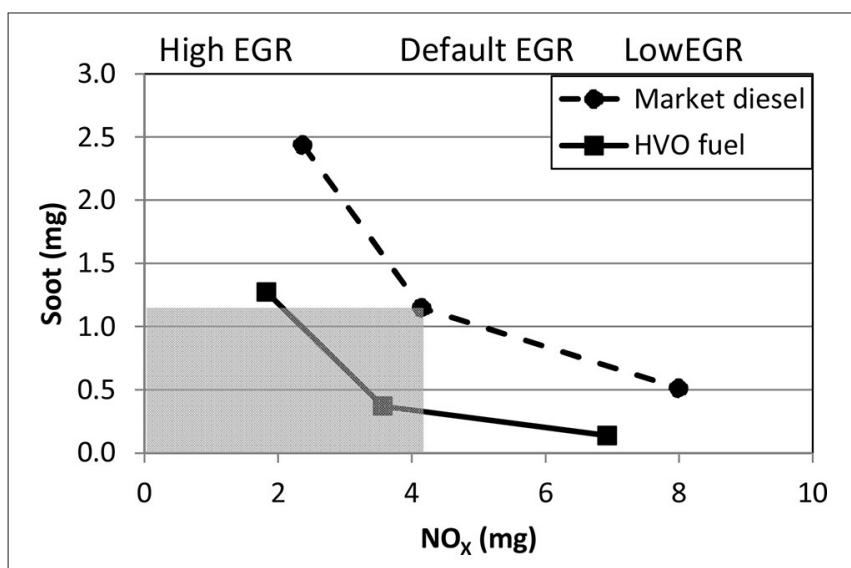

FIGURE 14 | Effect of EGR on the trade-off between NOx and soot emissions (2,000 rpm/70 Nm).
In general, EGR directly influences in-cylinder temperature field and therefore represents a measure for emission control without injection system adaptation. Results of all regulated emissions for the different EGR settings for the two operating points are shown in Figures 11, 12, respectively. $\mathrm{NO}_{\mathrm{x}}$ emissions are favored from (a) high in-cylinder temperature, (b) oxygen availability, and (c) residence time at high temperatures. The role of EGR is to recirculate a part of exhaust gases in the combustion chamber, reducing both combustion temperatures and oxygen availability. For the operating points that are examined here, $\mathrm{HVO}$ presents similar $\mathrm{NO}_{\mathrm{x}}$ emissions compared to market diesel (Figures 11, 12). As expected, EGR increase results in lower $\mathrm{NO}_{\mathrm{x}}$ emissions for both fuels. From Figures 11, 12 it is observed that the EGR rate is slightly different between the two fuels in all three cases that were examined. Tables 4, 5 present the absolute values of EGR valve position in each case for both fuels. Factors contributing to lower $\mathrm{NO}_{\mathrm{x}}$ emissions with the HVO fuel is the zero oxygen and aromatic content of the fuel compared to market diesel.

Concerning soot emissions, the increase of EGR results in higher emissions for both fuels. As shown in Figures 11, 12, the HVO fuel produces lower soot emissions in all cases of EGR rate

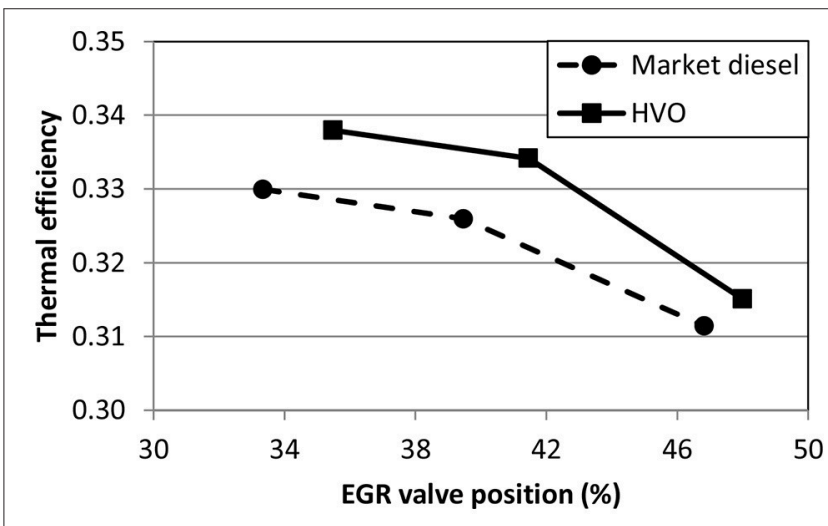

FIGURE 15 | Effect of EGR on thermal efficiency for both fuels $(1,500$ $\mathrm{rpm} / 70 \mathrm{Nm})$.

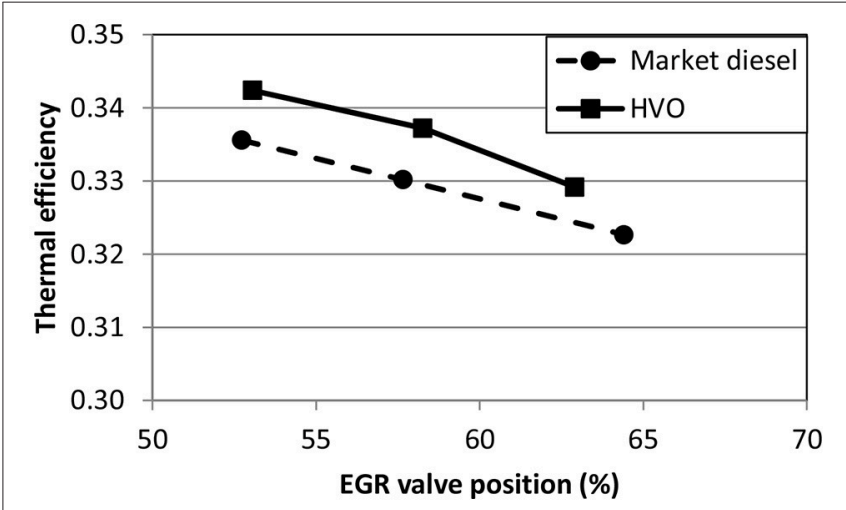

FIGURE 16 | Effect of EGR on thermal efficiency for both fuels $(2,000$ $\mathrm{rpm} / 70 \mathrm{Nm})$. 
compared to market diesel, owing to its paraffinic nature and zero aromatic content. Although in higher EGR rate HVO exhibits lower soot emissions compared to market diesel, these are still higher compared to the ones of market diesel at the default EGR setting.

The effect of EGR on the trade-off between soot and $\mathrm{NO}_{\mathrm{x}}$ emissions for both fuels is presented in Figures 13, 14, for the two operating points examined here. The gray area is the target area where both $\mathrm{NO}_{\mathrm{x}}$ and soot emissions are lower compared to market diesel, with the default EGR setting of the engine. It can be observed that $\mathrm{HVO}$ produces lower soot and $\mathrm{NO}_{\mathrm{x}}$ emissions compared to market diesel, at the default EGR setting. According to Figures 13, 14, an increase of EGR reduces further $\mathrm{NO}_{\mathrm{x}}$ emissions, however higher soot emissions are experienced.
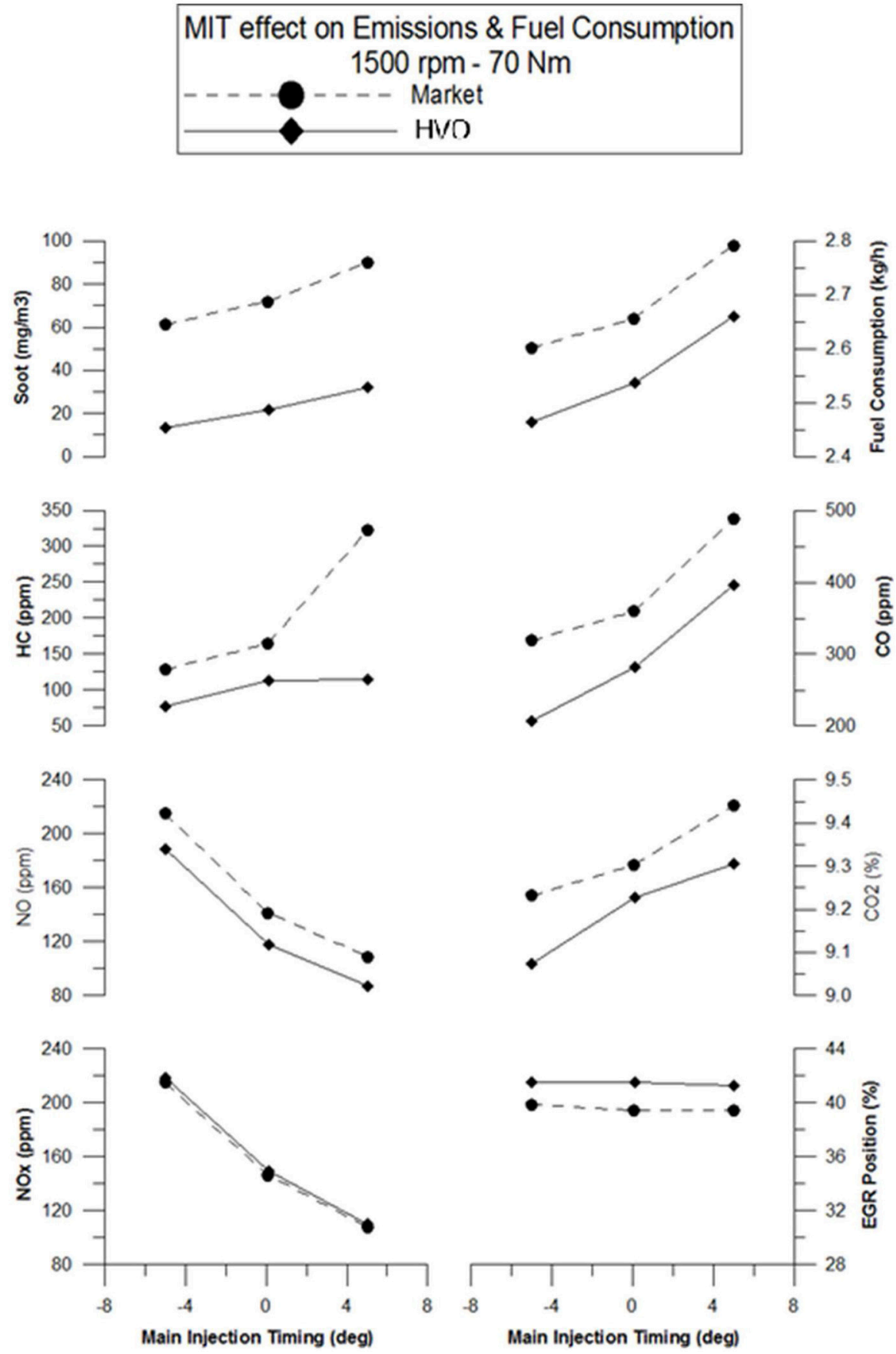

FIGURE 17 | MIT effect on emissions and fuel consumption for HVO and Market Diesel at 1,500 rpm and $70 \mathrm{Nm}$. 
It can be concluded, thus, that by changing solely the EGR rate a better trade-off between $\mathrm{NO}_{\mathrm{x}}$ and soot emissions cannot be achieved with the HVO fuel.

Similar profile with soot emissions also follow $\mathrm{HC}$ and $\mathrm{CO}$ emissions. In general, $\mathrm{HC}$ emissions are low for diesel engines; however, the use of HVO reduces them further compared to market diesel at default EGR setting. The effect of EGR rate for both fuels on $\mathrm{HC}$ and $\mathrm{CO}$ emissions is presented in Figures 11, 12. At higher EGR rate, the mixture heterogeneity increases, resulting in higher $\mathrm{HC}$ emissions, enhanced also by the prolonged ignition delay. However, in case of the HVO fuel, at higher EGR rate $\mathrm{HC}$ emissions remain at a lower level compared to market diesel at default EGR rate. This indicated that HVO provides the flexibility to increase the EGR rate without penalties on HC
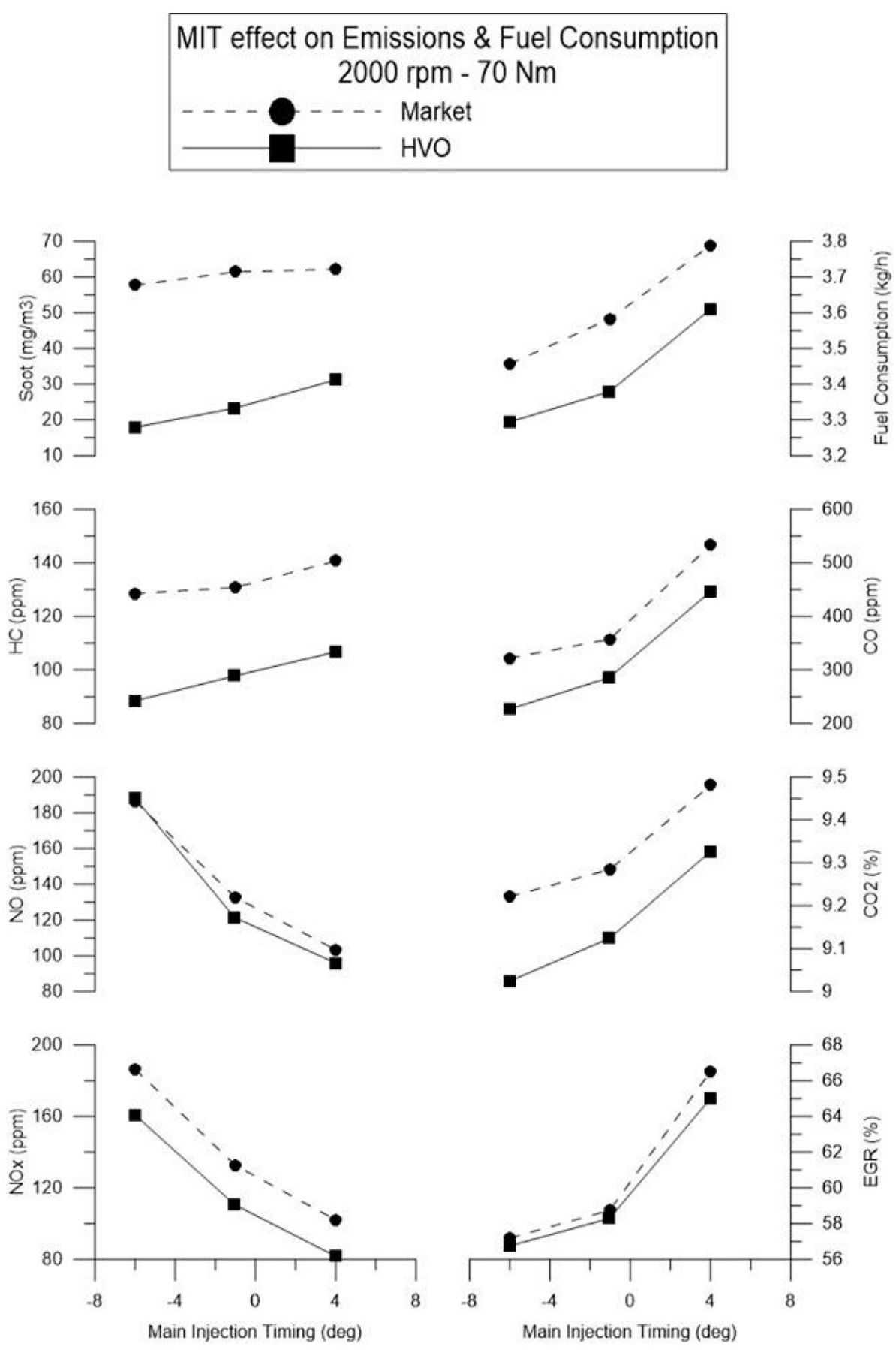

FIGURE 18 | MIT effect on emissions and fuel consumption for HVO and Market Diesel at 2,000 rpm and $70 \mathrm{Nm}$. 
emissions. On the other hand, $\mathrm{CO}$ emissions are significantly higher for increased EGR for both fuels.

Further, the effect of EGR on $\mathrm{CO}_{2}$ emissions and fuel consumption is also depicted in Figures 11, 12. By comparing the two fuels, it is easily observed that HVO and market diesel presents almost similar $\mathrm{CO}_{2}$ emissions at default EGR rate. Furthermore, an increase of EGR rate results in higher $\mathrm{CO}_{2}$ emissions with similar trends for both fuels. Concerning mass fuel consumption, the fuel property that has the largest effect is heating value (per mass unit), which is higher for HVO, resulting in slightly lower fuel consumption. Figures 11, 12 also present the main injection timing of the engine for the various EGR rates for comparison purposes; it is obvious that MIT remained constant throughout these tests, not affecting engine performance and emissions.

Finally, Figures 15, 16 present the effect of EGR on thermal efficiency for both fuels. It is observed that HVO presents slightly higher thermal efficiency in all EGR cases compared to market diesel which comes in agreement with the results of other studies (Aatola et al., 2008; Duckhan et al., 2014). The reason is the higher cetane number and the zero oxygen content of HVO fuel which results in the higher thermal efficiency at the current operating points $(1,500 \mathrm{rpm} / 70 \mathrm{Nm}$ and $2,000 \mathrm{rpm} / 70 \mathrm{Nm})$. However, this is not a general conclusion but characterize only the current operating points. As far as the effect of EGR is concerned, Figures 15, 16 show that the energy efficiency was slightly reduced with the increase of EGR for both fuels, which is expected as there is less fresh air available for combustion process (Duckhan et al., 2014).

\section{MIT Effect}

Three different main injection timings (MIT) were examined, including the default setting, $5^{\circ} \mathrm{CA}$ advanced and $5^{\circ} \mathrm{CA}$ retarded for both fuels, at the same operating points of 1,500 $\mathrm{rpm} / 70 \mathrm{Nm}$ and 2,000 rpm/70 Nm. Figures 17, 18 present the effect of MIT on $\mathrm{NO}_{\mathrm{x}}$, soot, $\mathrm{CO}_{2}, \mathrm{CO}$, and $\mathrm{HC}$ emissions, as well as on mass fuel consumption (the negative values correspond to timings before TDC). Figures 19, 20 present the trade-off between $\mathrm{NO}_{\mathrm{x}}$ and soot emissions on different MIT settings.

In general, advanced MIT results in earlier start of combustion, leading to higher combustion pressure and temperature that promote $\mathrm{NO}_{\mathrm{x}}$ formation, independently of the fuel. The change of MIT has very similar effects on both fuels, as presented in Figures 17, 18, where not a clear difference between market diesel and the HVO fuel can be distinguished at 1,500 rpm (Figure 17). On the other hand, significant difference is observed at 2,000 rpm (Figure 18) with HVO to present lower $\mathrm{NO}_{\mathrm{x}}$ emissions in all cases.

As far as soot emissions are concerned, similar trends are observed for both fuels, however the absolute concentration of soot is much lower for HVO in all MIT settings. The main reasons for this observation have been already analyzed in previous sections. The most interesting findings are presented in Figures 19, 20, where the trade-off between $\mathrm{NO}_{\mathrm{x}}$ and soot emissions at different MIT for both fuels is shown. The gray area

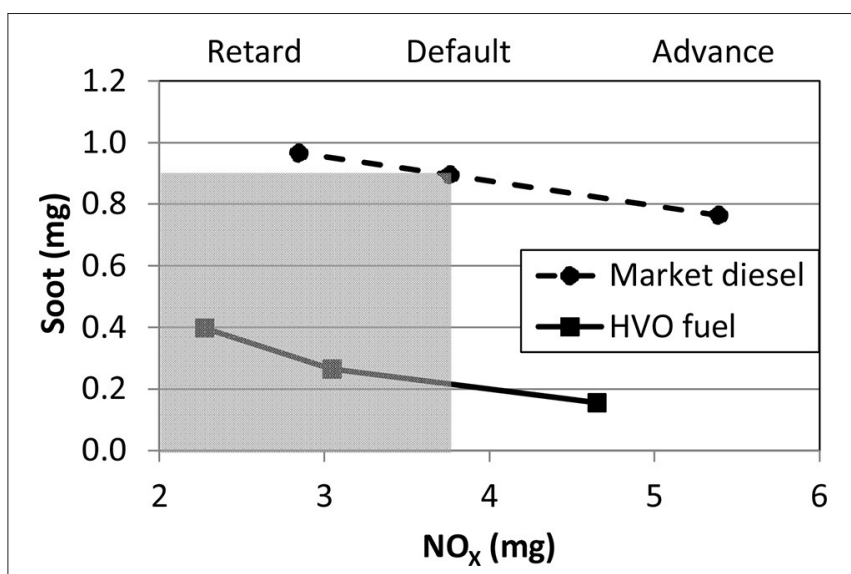

FIGURE 19 | Effect of MIT on the trade-off between $\mathrm{NO}_{x}$ and soot emissions (1,500 rpm/70 Nm).

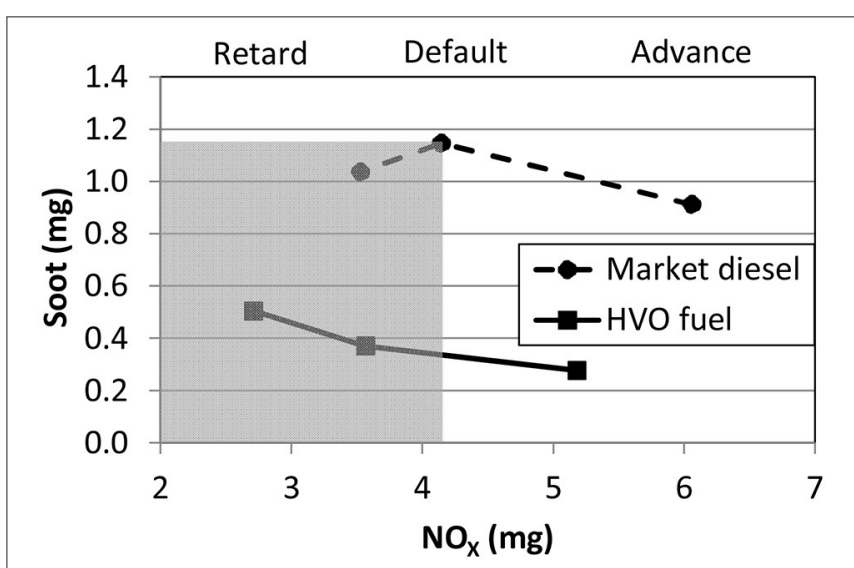

FIGURE 20 | Effect of MIT on the trade-off between $\mathrm{NO}_{x}$ and soot emissions (2,000 rpm/70 Nm).

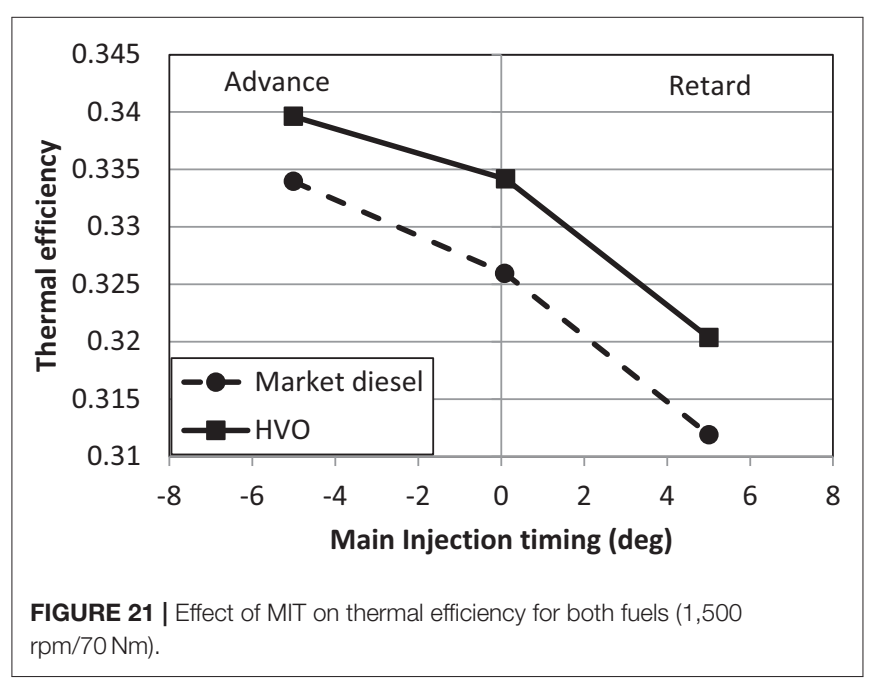

presents the target area where both soot and $\mathrm{NO}_{\mathrm{x}}$ emissions are lower compared to market diesel at the default MIT setting of the engine. It can be observed that in case of HVO at retarded 


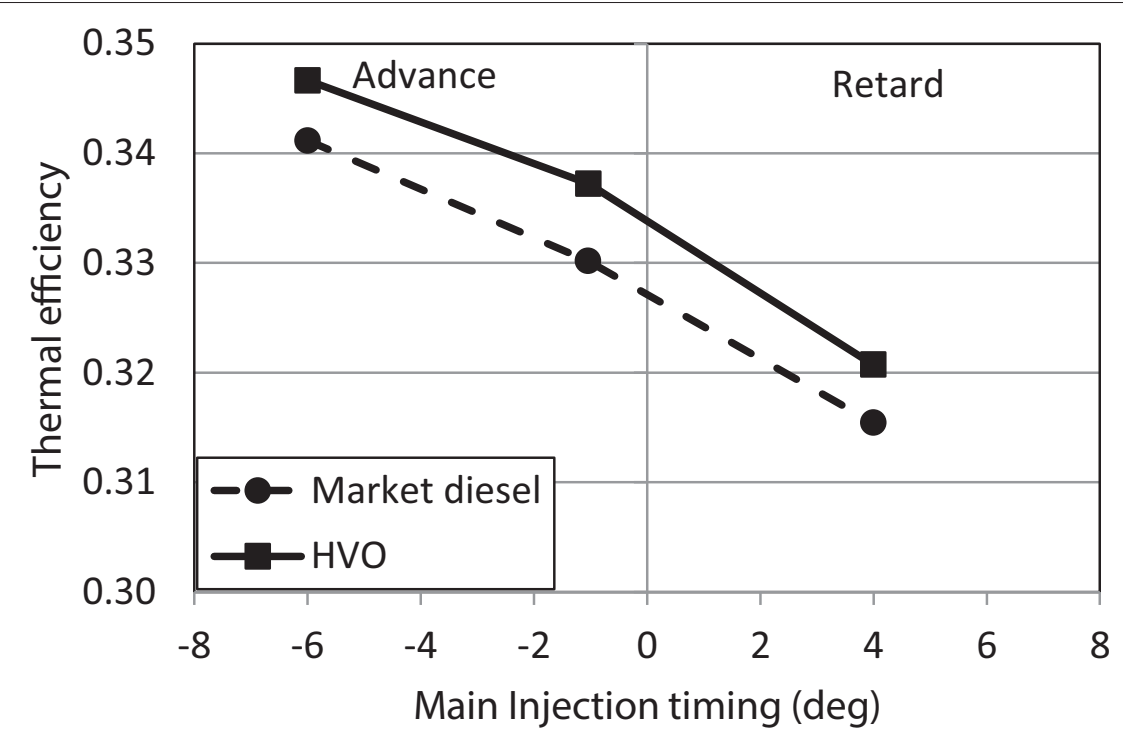

FIGURE 22 | Effect of MIT on thermal efficiency for both fuels (2,000 rpm/70 Nm).

MIT, although soot emissions are increased, they still remain at a lower level compared to market diesel at default MIT setting. This indicates that retardation of MIT with the HVO fuel can be a proper strategy in order to reduce $\mathrm{NO}_{\mathrm{x}}$ and soot emissions simultaneously.

The effect of MIT on HC and CO emissions is also presented in Figures 17, 18. It is observed that when the MIT is advanced, the trends of $\mathrm{HC}$ emissions are similar for both fuels. At the case of retarded MIT, HC emissions were significantly increased for market diesel, while they received only slightly higher values for HVO. In any case, the HVO fuel presents lower $\mathrm{HC}$ emissions in all MIT settings, compared to market diesel. Concerning CO concentration, again similar trends are observed for both fuels, with the HVO fuel producing lower CO emissions in all MIT settings.

Further, the effect of MIT on $\mathrm{CO}_{2}$ emissions and fuel consumption is also depicted in Figures 17, 18. As expected, when the MIT is advanced fuel consumption is reduced for both fuels, since higher pressures are developed during the combustion process. For the case of HVO, fuel consumption remains lower in all MIT settings, as compared to market diesel, owing to its higher heating value per mass unit. Regarding $\mathrm{CO}_{2}$ emissions, again at the case of HVO, these remain at lower levels for all MIT settings, as compared to market diesel, due to the lower carbon content of the HVO fuel, as well as due to the lower mass-based fuel consumption.

Based on the findings of this section, it is indicated that $\mathrm{HVO}$ offers the potential to reduce $\mathrm{NO}_{\mathrm{x}}$ and soot emissions simultaneously by modifying suitably the injection timing. Of course, this is a first indication and further research is under way by the current research group.

Finally, Figures 21, 22 present the effect of the MIT strategies on thermal efficiency for both fuels. As it was already discussed previously HVO presents higher thermal efficiency at the current operating points. As expected, thermal efficiency increases with advanced MIT and decreases with retarded MIT. Advanced injection timing results in higher in cylinder pressures and temperatures, while the opposite effect is experienced when the injection timing is retarded.

\section{SUMMARY AND CONCLUSIONS}

In the present work, a non-oxygenated bio-based fuel (HVO) of paraffinic nature was studied and compared with market diesel in a light-duty common rail Euro 5 engine. Exhaust emissions under steady-state operation and during the NEDC were evaluated. Furthermore, the effect of EGR and Main Injection Timing (MIT) on exhaust emissions at steady-state operation with both tested fuels was examined. The use of the HVO fuel enables appreciable reductions in soot, $\mathrm{HC}$ and $\mathrm{CO}$ emissions without any modification to the engine control. However, the effect of the $\mathrm{HVO}$ fuel on $\mathrm{NO}_{\mathrm{x}}$ emission is not clear.

The results have shown that retarding the injection timing may be a good option for reducing simultaneously $\mathrm{NO}_{\mathrm{x}}$ and soot emissions with the HVO fuel, since the penalty in soot is limited. Actually, soot emissions with the HVO fuel at retarded injection timing remain lower than the respective values with market diesel at default MIT setting, while the other emissions receive also lower values compared to market diesel. Of course, the fuel consumption penalty must be also considered, which, however, is lower for the HVO fuel. This does not seem to be the case with EGR, which was found to influence emissions in a similar manner for both fuels, with the penalty being lower for the HVO fuel at increased EGR rate, while $\mathrm{NO}_{\mathrm{x}}$ reduction did not present any appreciable difference between the two fuels. However, more studies have to be made in order to end up to general conclusions concerning the effect of EGR and injection strategy. 


\section{AUTHOR CONTRIBUTIONS}

ADimit worked on data processing and drafted the text of the paper. IN worked on the main part of experimental data processing. ADimar made the critical revision of the experimental results and the text of the paper. DK was responsible for the experimental activity. ZS had the overall management of the work and reviewed the paper. SB reviewed the paper. KL provided the HVO fuel and reviewed the paper.

\section{FUNDING}

The authors would like to acknowledge support of this work by the project Development of the Research

\section{REFERENCES}

Aatola, H., Larmi, M., Sarjovaara, T., and Mikkonen, S. (2008). Hydrotreated Vegetable Oil (HVO) as a Renewable Diesel Fuel: Trade-off between $\mathrm{NO}_{x}$, Particulate Emission, and Fuel Consumption of a Heavy-Duty Engine. SAE World Congress. Paper No. 2008-01-2500.

Alleman, T. L., and McCormick, R. L. (2003). Fischer-Tropsch Diesel Fuels Properties and Exhaust Emissions: A Literature Review. SAE World Congress. Paper No. 2003-01-0763.

Armas, O., Garcva-Contreras, R., and Ramos, A. (2013). Impact of alternative fuels on performance and pollutant emissions of a light duty engine tested under the new European driving cycle. Appl. Energy 107, 183-190. doi: 10.1016/j.apenergy.2013.01.064

Bezergianni, S., and Dimitriadis, A. (2013). Comparison between different types of renewable diesel. Renew. Sustain. Energy Rev. 21, 110-116. doi: 10.1016/j.rser.2012.12.042

Duckhan, K., Seonghwan, K., Sehun, O., and Soo-Young, N. (2014). Engine performance and emission characteristics of hydrotreated vegetable oil in light duty diesel engines. Fuel 125, 36-43. doi: 10.1016/j.fuel.2014.01.089

Erkkila, K., Nylund, N., Hulkkone, T., Tilli, A., Mikkonen, S., Saikkonen, P., et al. (2011). Emission Performance of Paraffinic HVO Diesel Fuel in Heavy Duty Vehicles. SAE paper 2011-01-1966.

EurObserv'ER (2015). BIOFUELS BAROMETER. Available online at: http://www. energies-renouvelables.org/observ-er/stat_baro/observ/baro222_en.pdf

Fontaras, G., Karavalakis, G., Kousoulidou, M., Tzamkiozis, T., Ntziachristos, L., Bakeas, E., et al. (2009). Effects of biodiesel on passenger car fuel consumption, regulated and non-regulated pollutant emissions over legislated and real-world driving cycles. Fuel 88, 1608-1617. doi: 10.1016/j.fuel.2009.02.011

George, A., Ban-Weiss, J. Y., Chen Bruce, A., and Buchholz Robert, W. D. (2007). A numerical investigation into the anomalous slight $\mathrm{NO}_{\mathrm{x}}$ increase when burning biodiesel; a new (old) theory. Fuel Process. Technol. 88, 659-667. doi: 10.1016/j.fuproc.2007.01.007

Giakoumis, E. G., Rakopoulos, C. D., Dimaratos, A. M., and Rakopoulos, D. C. (2012). Exhaust emissions of diesel engines operating under transient conditions with biodiesel fuel blends. Prog. Energy Combust. Sci. 38, 691-715. doi: 10.1016/j.pecs.2012.05.002

Gill, S. S., Tsolakis, A., Dearn, K. D., and Rodríguez-Fernández, J. (2011). Combustion characteristics and emissions of Fischer-Tropsch diesel fuels in IC engines. Progr. Energy Combust. Sci. 37, 503-523. doi: 10.1016/j.pecs.2010.09.001

Glaude, P., Fournet, R., Bounaceur, R., and Molière, M. (2010). Adiabatic flame temperature from biofuels and fossil fuels and derived effect on $\mathrm{NO}_{\mathrm{x}}$ emissions. Fuel Process. Technol. 91, 229-235. doi: 10.1016/j.fuproc.2009.10.002

Graboski, M. S., and McCormick, R. L. (1998). Combustion of fat and vegetable oil derived fuels in diesel engines. Prog. Energy Combust. Sci. 24, 125-164. doi: 10.1016/S0360-1285(97)00034-8

Hajbabaei, M., Johnson, K. C., Okamoto, R. A., Mitchell, A., Pullman, M., and Durbin, T. D. (2012). Evaluation of the impacts of biodiesel and second
Infrastructure Centre of Excellence for Future Vehicle Environmental Performance - FuVEP (MIS 5002370) which is implemented under the Action Reinforcement of the Research and Innovation Infrastructure, funded by the Operational Programme Competiveness, Entrepreneurship and Innovation (NSRF 2014-2020) and co-financed by Greece and the European Union (European Regional Development Fund).

\section{SUPPLEMENTARY MATERIAL}

The Supplementary Material for this article can be found online at: https://www.frontiersin.org/articles/10.3389/fmech. 2018.00007/full\#supplementary-material generation biofuels on $\mathrm{NO}_{\mathrm{x}}$ emissions for CARB diesel fuels. Environ. Sci. Technol. 46, 9163-9173. doi: 10.1021/es300739r

Happonen, M., Heikkila, J., Aakko-Saksa, P., Murtonen, T., Lehto, K., Rostedt, A., et al. (2013). Diesel exhaust emissions and particle hygroscopicity with HVO fuel-oxygenate blend. Fuel 103, 380-386. doi: 10.1016/j.fuel.2012.09.006

Happonen, M., Heikkilä, J., Murtonen, T., Lehto, K., Sarjovaara, T., Larmi, M., et al. (2012). Reductions in particulate and $\mathrm{NO}_{\mathrm{x}}$ emissions by diesel engine parameter adjustments with HVO fuel. Environ. Sci. Technol. 46, 6198-6204. doi: $10.1021 /$ es300447t

Heywood, J. B. (1988). Internal Combustion Engines Fundamentals. New York, NY: McGraw-Hill.

Hooftman, N., Messagie, M., Van Mierlo, J., and Goosemans, T. (2018). A review of the European passenger car regulations - real driving emissions vs local air quality. Renew. Sustain. Energy Rev. 86, 1-21. doi: 10.1016/j.rser.2018. 01.012

Huang, Y., Wang, S., and Zhou, L. (2008). Effects of Fischer-Tropsch diesel fuel on combustion and emissions of direct injection diesel engine. Front. Energy Power Eng. China 2, 261-267. doi: 10.1007/s11708-008-0062-x

Karavalakis, G., Stournas, S., and Bakeas, E. (2009). Effects of diesel/biodiesel blends on regulated and unregulated pollutants from a passenger vehicle operated over the European and the Athens driving cycles. Atmos. Environ. 43, 1745-175. doi: 10.1016/j.atmosenv.2008.12.033

Kitano, K., Sakata, I., and Clark, R. (2005). Effects of GTL Fuel Properties on DI Diesel Combustion. SAE World Congress, Paper No. 2005-01-3763.

Kousoulidou, M., Dimaratos, A., Karvountzis-Kontakiotis, A., and Samaras, Z. (2014). Combustion and emissions of a common-rail diesel engine fueled with HWCO. J. Energy Eng. 140, 1-9. doi: 10.1061/(ASCE)EY.1943-7897. 0000154

Kousoulidou, M., Fontaras, G., Ntziachristos, L., and Samaras, Z. (2009). Evaluation of Biodiesel Blends on the Performance and Emissions of a CommonRail Light-Duty Engine and Vehicle. SAE World Congress 2009. Paper No. 2009-01-0692.

Kousoulidou, M., Fontaras, G., Ntziachristos, L., and Samaras, Z. (2010). Biodiesel blend effects on common-rail diesel combustion and emissions. Fuel 89, 3442-3449. doi: 10.1016/j.fuel.2010.06.034

Kousoulidou, M., Ntziachristos, L., Fontaras, G., Martini, G., Dilara, P., and Samaras, Z. (2012). Impact of biodiesel application at various blending ratios on passenger cars of different fueling technologies. Fuel 98, 88-94. doi: 10.1016/j.fuel.2012.03.038

Kuronen, M., Mikkonen, S., Aakko, P., and Mwtonen, T. (2007). Hydrotreated Vegetable Oil as Fuel for Heavy Duty Diesel Engines. SAE World Congress, Paper No. 2007-01-4031.

Lindfors, L. P. (2010). High Quality Transportation Fuels From Renewable Feedstock. Neste Corporation. XXIst World Energy Congress Montreal, Canada September 12-16.

Makinen, R., Nylund, N., Erkkila, K., Amberla, A., and Saikonen. (2011). Bus Fleet Operation on Renewable Paraffinic Diesel Fuel. SAE Technical paper 2011-01-1965. 
Mikkonen, S., Hartikka, T., Kuronen, M., and Saikkonen, P. (2012). HVO, Hydrotreated Vegetable Oil - a Premium Renewable Biofuel for Diesel Engines. Neste Proprietary Publication.

Mizushima, N., Sato, S., Kawano, D., Saito, A., and Takada, Y. (2012). A Study on $\mathrm{NO}_{x}$ Emission Characteristics When Using Biomass-Derived Diesel Alternative Fuels. SAE World Congress 2012, Paper 2012-01-1316.

Murtonen, T., and Aakko-Saksa, P. (2009). Alternative Fuels With Heavy-Duty Engines and Vehicles. VTTs Contribution. Julkaisija Utgivare Publisher, VTT Working Papers, 128, 109-117.

Murtonen, T., Aakko-Saksa, P., Kuronen, M., Mikkonen, S., and Lehtoranta, K. (2009). Emissions With Heavy-Duty Diesel Engines and Vehicles Using FAME, HVO and GTL Fuels With and Without DOC+POC Aftertreatment. SAE paper 2009-01-2693.

Pflaum, H., Hofmann, P., Geringer, B., and Weissel, W. (2010). Potential of Hydrogenated Vegetable Oil (HVO) in a Modern Diesel Engine. SAE paper 2010-32-0081.

Rakopoulos, C. D., Antonopoulos, K. A., Rakopoulos, D. C., Hountalas, D. T., and Giakoumis, E. G. (2006). Comparative performance and emissions study of a direct injection Diesel engine using blends of Diesel fuel with vegetable oils or bio-diesels of various origins. Energy Conversion Manage. 47, 3272-3287. doi: 10.1016/j.enconman.2006.01.006

Rakopoulos, C. D., Rakopoulos, D. C., Hountalas, D. T., Giakoumis, E. G., and Andritsakis, E. C. (2008). Performance and emissions of bus engine using blends of diesel fuel with bio-diesel of sunflower or cottonseed oils derived from Greek feedstock. Fuel 87, 147-157. doi: 10.1016/j.fuel.2007.04.011

Rantanen, L., Linnaila, R., Aakko, P., and Harju, T. (2005). NExBTL - Biodiesel Fuel of the Second Generation. SAE World Congress, Paper No. 2005-01-3771.

Rimkus, A., Zaglinskis, J., Rapalis, P., and Skackauskas, P. (2015). Research on the combustion, energy and emission parameters of diesel fuel and a biomass-to-liquid (BTL) fuel blend in a compression-ignition. Energy Conversion Manage. 106, 1109-1117. doi: 10.1016/j.enconman.2015. 10.047

Semelsberger, T. A., Borup, R. L., and Greene, H. L. (2006). Dimethyl ether (DME) as an alternative fuel. J. Power Sources 156, 497-511. doi: 10.1016/j.jpowsour.2005.05.082

Šimacek, P., Kubicka, D., Šebor, G., and Pospišil, M. (2010). Fuel properties of hydroprocessed rapeseed oil. Fuel 89, 611-615. doi: 10.1016/j.fuel.2009.09.017

Soo-Young, N. (2014). Application of hydrotreated vegetable oil from triglyceride based biomass to CI engines - a review. Fuel 115, 88-96. doi: 10.1016/j.fuel.2013.07.001

Sugiyama, K., Goto, I., Kotano, K., Mogi, K., and Honkanen, M. (2011). Effects of Hydrotreated Vegetable Oil (HVO) as Renewable Diesel Fuel on Combustion and Exhaust Emissions in a Diesel Engine. SAE paper 2011:01-1954.

Conflict of Interest Statement: KL was employed by company Neste Oil Corporation.

The remaining authors declare that the research was conducted in the absence of any commercial or financial relationships that could be construed as a potential conflict of interest.

Copyright (C) 2018 Dimitriadis, Natsios, Dimaratos, Katsaounis, Samaras, Bezergianni and Lehto. This is an open-access article distributed under the terms of the Creative Commons Attribution License (CC BY). The use, distribution or reproduction in other forums is permitted, provided the original author(s) and the copyright owner(s) are credited and that the original publication in this journal is cited, in accordance with accepted academic practice. No use, distribution or reproduction is permitted which does not comply with these terms. 